Published in final edited form as:

Nat Protoc. 2020 February ; 15(2): 628-648. doi:10.1038/s41596-019-0263-2.

\title{
Long-term ex vivo expansion of mouse hematopoietic stem cells
}

\author{
Adam C. Wilkinson ${ }^{1,2}$, Reiko Ishida ${ }^{3,4}$, Hiromitsu Nakauchi ${ }^{1,2,3,5}$, Satoshi Yamazaki ${ }^{4,5}$ \\ ${ }^{1}$ Institute for Stem Cell Biology and Regenerative Medicine, Stanford University School of \\ Medicine, Lorry I. Lokey Stem Cell Research Building, 265 Campus Drive, Stanford, CA, USA \\ ${ }^{2}$ Department of Genetics, Stanford University School of Medicine, Stanford, CA, USA \\ ${ }^{3}$ Division of Stem Cell Therapy, Distinguished Professor Unit, The Institute of Medical Science, \\ The University of Tokyo, Tokyo 108-8639, Japan \\ ${ }^{4}$ Division of Stem Cell Biology, Center for Stem Cell Biology and Regenerative Medicine, The \\ Institute of Medical Science, The University of Tokyo, Tokyo 108-8639, Japan
}

\begin{abstract}
Utilizing multipotent and self-renewing capabilities, hematopoietic stem cells (HSCs) can maintain hematopoiesis throughout life. However, the mechanism of such striking abilities remains unanswered, at least in part because of the paucity of HSCs and the modest ex vivo expansion of HSCs in medias that contain poorly-defined albumin supplements such as bovine serum albumin. Here, we describe a simple platform to expand functional mouse HSCs ex vivo for $>1$ month using a fully-defined albumin-free condition. The culture system affords 236-899-fold expansion over the course of a month and is also amenable to clonal analysis of HSC heterogeneity. The large numbers of expanded HSCs also enable HSC transplantation in nonconditioned recipients, an assay that is otherwise not routinely feasible due to the large numbers of HSCs required. This protocol therefore provides a powerful approach to interrogate HSC self-renewal and lineage commitment, and more broadly study and characterize the hematopoietic and immune systems.
\end{abstract}

\section{EDITORIAL SUMMARY}

Functional mouse hematopoietic stem cells (HSCs) are expanded 236-899-fold ex vivo using a fully-defined albumin-free culture system. Clonal analysis of HSC heterogeneity and HSC transplantation are also described.

\footnotetext{
${ }^{5}$ Corresponding authors y-sato4@ims.u-tokyo.ac.jp (S.Y); nakauchi@ stanford.edu (H.N).

AUTHOR CONTRIBUTION STATEMENT: ACW designed and validated the protocol, and wrote and edited the manuscript. RI designed and validated the protocol, and edited the manuscript. HN supervised the research and edited the manuscript. SY designed and validated the protocol, supervised the research, and edited the manuscript.

COMPETING INTERESTS: H.N. is a co-founder and shareholder of ReproCELL. Inc.

DATA AVAILABILITY STATEMENT: All raw data are available upon reasonable request.

RELATED LINKS

Key reference using this protocol:Wilkinson AC, Ishida R, Kikuchi M, et al. Long-term ex vivo haematopoietic-stem-cell expansion allows nonconditioned transplantation. Nature. 2019; 571(7763):117-121.
}

TWEET Protocol for the ex vivo expansion of hematopoietic stem cells.

COVER TEASER HSC expansion 


\section{Keywords}

Hematopoietic stem cell; polyvinyl alcohol; ex vivo culture; self-renewal

\section{INTRODUCTION}

Bone marrow-derived self-renewing and multipotent hematopoietic (blood-forming) stem cells (HSCs) are responsible for homeostasis of the blood and immune systems ${ }^{1-4}$. HSCs are functionally defined by transplantation into a bone marrow-ablated recipient, where even at the clonal level they display the capacity to reform and maintain the entire adult blood system for the life of the recipient ${ }^{5}$. Over the last few decades, this elegant functional assay has been widely used to phenotype bone marrow HSCs, and to study the genetic, epigenetic, and metabolic regulation of HSC function and blood system homeostasis ${ }^{1-4}$. These unique properties of HSCs are also utilized clinically in a form of bone marrow transplantation (HSC transplantation or HSCT), which represents the only curative therapy for a range of blood and immune diseases ${ }^{6}$. However, despite substantial interest in HSCs from both scientific and clinical perspectives, existing culture conditions poorly-maintain and minimally-expand HSCs, and support only short-term ( 1 week) ex vivo culture ${ }^{7}$. Here, we describe a robust and reproducible protocol to culture mouse HSCs long-term (1-2 months) ex vivo in fully-defined albumin-free conditions. Through split-clone transplantation experiments and limiting dilution analysis, we have recently demonstrated that this protocol enables ex vivo HSC self-renewal and can support a 236-899-fold expansion of functional HSCs over the course of a 1-month culture ${ }^{8}$.

\section{Development of the protocol}

To develop this protocol, we took a reductionist approach to optimize the culture conditions for mouse HSCs. Rather than searching for additional "HSC factors", we found that the constituents of existing culture systems, and associated culture protocols, were poorly optimized and contaminants within media supplements inhibited HSC expansion ${ }^{8}$. By optimizing a minimal media condition, we were able to dramatically improve mouse HSC expansion cultures, from conditions that supported $\sim 1$-week cultures and generated $<10$-fold HSC expansion ${ }^{9}$, to long-term (1-2-month) cultures that support up to 266-899-fold expansion of functional $\mathrm{HSCs}^{8}$. Briefly, this was achieved by sequentially optimizing: cytokine concentrations (and ratios); type of media changes; type of extracellular matrix plate-coating; and complete removal of serum albumin. The resulting HSC culture protocol, detailed here, provides a major advance in our ability to expand and study this important stem cell population ex vivo.

\section{Applications of the method}

HSCs are a very rare cell population within the bone marrow, and only a few thousand can be isolated from a single mouse ${ }^{10,11}$. Performing molecular or biochemical assays using HSCs has therefore been challenging to date as collection from tens or hundreds of mice is often required ${ }^{12}$, with significant financial, time, and ethical costs. The ex vivo expansion of functional mouse HSCs is thus helpful as it enables us to study this important stem cell 
population, and increase the types of assays that can be performed on them (without substantial animal usage). This HSC expansion method therefore has numerous potential applications including the study of the genetic, epigenetic, and metabolic regulation of HSC function; the generation of HSCs for cellular, molecular, and biochemical analysis; and to perform screening (e.g. genetic or small molecule screening). This characterization of the HSC state will ultimately help us to better understand how blood system homeostasis is maintained (and is lost in hematological diseases) as well as improve on current methods to perform clinical HSCT and related ex vivo HSC gene therapies. With the ability of HSCs to form any adult blood and immune cell type following transplantation ${ }^{1-4}$, this method also has wider application for studying other biological processes, e.g. innate and adaptive immunity, red blood cell and platelet biology, and tissue-resident immune cell biology (e.g. microglial biology).

\section{Comparison with other methods}

In comparison with other mouse HSC culture methods ${ }^{7}$, our protocol affords long-term expansion of HSCs (1-2 months) and large-expansion of functional HSCs (estimated at 236-899-fold over a month) ${ }^{8}$. Although existing protocols used similar media reagents, previous methods were generally limited to $\sim 1$ week cultures and afforded $<10$-fold expansion of functional HSCs ${ }^{9}$. The use of thrombopoietin (TPO) and stem cell factor (SCF) cytokines in mouse HSC cultures has been well-described previously $9,13,14$, although other laboratories have used alternative cytokines to TPO, such as interlukin-11 (IL-11) or IL-12. However, to date protocols have generally used $50 \mathrm{ng} / \mathrm{ml}$ TPO and $50 \mathrm{ng} / \mathrm{ml} \mathrm{SCF}^{9}$. By titrating the concentration of these cytokines, we found that $100 \mathrm{ng} / \mathrm{ml}$ TPO and $10 \mathrm{ng} / \mathrm{ml}$ SCF were optimal for mouse HSC cultures ${ }^{8}$. This combination of cytokines preferentially

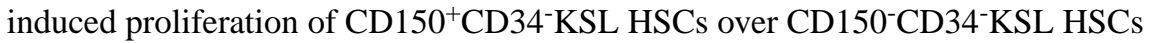
(representing phenotypic long-term and short-term HSCs, respectively ${ }^{10,15,16}$ ) and CD $34^{+}{ }^{K S L}$ hematopoietic progenitor cells ${ }^{5}$ (HPCs). We believe that this preferential induction of HSC proliferation within our culture is important to prevent HSCs being outcompeted within the long-term cultures.

To date, all reported HSC culture media have included serum albumin ${ }^{7}$, in the form of fetal bovine serum (FBS), bovine serum albumin (BSA), or recombinant serum albumin (RSA). These serum albumin supplements have represented a major source of poorly-defined biological contaminants in HSC cultures, which have influenced the reproducibility of results, stability of the cultures, and even the effect of cytokines on HSC maintenance ${ }^{9}$. A key difference between these existing methods and the one described here is the use of polyvinyl alcohol (PVA) as a serum albumin replacement ${ }^{8}$. PVA is a synthetic polymer that is generated by hydrolysis of polyvinyl acetate. This protocol uses incompletely ( $\sim 87 \%)$ hydrolyzed PVA, which is an amphiphilic polymer containing both hydrophilic alcohol domains and hydrophobic acetate domains. We found that this amphiphilic property of PVA was important for the rapid proliferation of HSCs, although not long-term ex vivo selfrenewal ${ }^{8}$. 


\section{Experimental design}

This protocol provides a step-by-step guide to perform mouse HSC expansion culture and transplantation. It can be divided into three stages: (1) collecting mouse HSCs; (2) bulk and clonal culture of mouse HSCs; and (3) in vitro analysis and in vivo transplantation assays using nonirradiated and irradiated recipients (Figure 1). The protocols can be modified, for example experienced HSC biologists may prefer to use their own methods for collecting mouse HSCs and/or functional assays. The basic HSC cultures can be modified for different uses, e.g. testing the consequences of additional molecules on HSC function. This procedure has been optimized for HSCs collected from 8-12-week old C57BL/6-CD45.1 (PepboyJ) donor mice and transplantation into 8-12-week old C57BL/6-CD45.2 (and C57BL/6CD45.1/CD45.2) recipient mice. While we expect that HSC expansion should be similar using other mouse strains (and/or different aged donors), we cannot predict how the purity or stability of the cultures may differ.

Collecting mouse HSCs (steps 1-18)-There are a number of detailed protocols available for collecting mouse HSCs ${ }^{17-20}$. Here, we describe the HSC isolation protocol routinely used by our laboratory, which is based on the use of CD34 and CD150 to resolve the mouse bone marrow $\mathrm{Kit}^{+} \mathrm{Sca} 1^{+}$Lineage $(\mathrm{Lin})^{-}(\mathrm{KSL})$ hematopoietic stem and progenitor cell compartment. However, we expect other protocols (and/or alternative phenotypic HSC populations) should work to a similar extent. It is worth noting that to ensure that the HSC cultures are albumin-free, this protocol uses only PBS for all wash/staining steps in this protocol (rather than the common use of FBS or BSA supplemented PBS or media). When planning experimental set up, it is best to assume that $1-2 \times 10^{3} \mathrm{HSCs}$ will be collectable from each donor 8-12-week old C57BL/6 mouse.

Bulk culture of mouse HSCs (step 19A)-Here, we describe our optimized HSC expansion culture system. This protocol provides a simple but reproducible approach to grow mouse HSCs ex vivo for up to 1-2 months. The culture system is designed to provide a basic platform to grow, study, and interrogate mouse HSCs ex vivo. For example, users may want to test the consequences of addition of other cytokines or small molecules on the HSC cultures, or to assess how HSCs collected from different mouse strains perform in these HSC cultures.

Clonal culture of mouse HSCs (step 19B)—Here, we describe a variant of the mouse HSC culture protocol for generating clonally-derived HSC cultures. This method provides a powerful approach to investigate the clonal heterogeneity of the HSC compartment and the self-renewal potential of single cells that is masked by bulk cell cultures. Due to the functional heterogeneity of phenotypic HSCs at the single cell level, we recommend analyzing at least $48-96$ cells per donor.

In vitro analysis of HSC cultures (steps 20-24)-Here, we describe basic methods for assessing the growth and stability of mouse HSC cultures (both bulk and clonal), by cell counting and flow cytometric analysis. Users may also want to perform their assay-ofinterest using expanded HSCs, but we recommend checking the growth and phenotype of the cultures before moving onto functional and/or molecular assays. 
Transplantation analysis in nonconditioned recipients (step 25A)-The engraftment of HSCs in nonconditioned recipients has been described elsewhere ${ }^{21,22}$. However, these methods use very large numbers of freshly-isolated HSCs and are therefore essentially unfeasible for routine use due to the number of donor mice required to achieve robust levels of engraftment (often 10-50 donor mice/recipient). Here, we describe the transplantation of ex vivo expanded HSCs, which allows just 50-100 freshly-isolated HSCs to robustly engraft in nonconditioned recipient mice following expansion and transplantation ${ }^{8}$. We expect that this method opens up nonconditioned transplantation into immunocompetent mice for wider use by the research community.

\section{Competitive transplantation analysis in irradiated recipients (step 25B)-}

Competitive transplantation assays are widely used in the hematology field and a number of detailed protocols have been published previously ${ }^{23}$. Here, we detail the competitive transplantation assay protocol used by our laboratory, to provide new users with a functional assay to readout the activity of their HSC cultures. In the competitive transplantation assay detailed here, $\mathrm{CD} 45.1^{+}$donor HSCs are competed against a set number of CD45.1 $1^{+} \mathrm{CD} 45.2^{+}$ whole bone marrow competitor cells $\left(1 \times 10^{6}\right.$ cells $)$ within a $\mathrm{CD} 45.2^{+}$recipient mouse.

\section{Expertise needed to implement the protocol}

The basic HSC culture protocol is relatively simple for researchers trained in cell biology (e.g. graduate or postdoctoral students), although it is important that the user has expertise in aseptic tissue-culture technique, and experience with mammalian cell culture. The most technically challenging step during the HSC culture is correctly performing the media changes. Complete media changes (but without adversely disturbing the cells) is key for successful long-term ex vivo HSC expansion. Substantial expertise is required for the safe and accurate operation of fluorescence-activated cell sorting (FACS) and for performing animal experimentation (transplantation assays). Although necessary facilities should be available at most research institutions, both require substantial training, and may also require certification (depending on the institution and country) as well as protocol approval from institutional and/or national regulators. We recommend that new users identify and collaborate with institutional core facilities and associated technical staff to perform these steps of the protocol if these assays are not routinely performed.

\section{Limitations}

A current limitation of this method is that although we can expand functional HSCs by an estimated 236-899-fold in these culture conditions over 28-days, the cell culture is not functionally homogeneous because the media can support growth of certain other cell types. Limiting dilution transplantation analysis estimated that 1:34 cells retained HSC activity in the day- 28 cultures $^{8}$. To date, we do not yet have a reliable marker to isolate ex vivo expanded HSCs, although we believe that the phenotype should be similar to bone marrow HSCs (e.g. display a KSL phenotype). As we also do not have a reliable phenotype to purify self-renewing HSCs from the bone marrow, with the phenotypic HSC compartment remaining functionally heterogeneous ${ }^{10,11,24}$, this is perhaps unsurprising. 
A second limitation of this protocol is that although this protocol eliminates batch-variable serum albumin supplements, we currently cannot exclude the potential batch variability of other media reagents. In particular, cytokine batches can represent a potential source of variability. We recommend purchasing large amounts of cytokines to reduce the need to change batches regularly. Additionally, we recommend that old and new cytokine batches are compared before new batches are used. Bulk cell HSC cultures should be highly reproducible once the experimental set up is standardized ${ }^{8}$. However, it is worth noting that changing the starting HSC phenotype (or sort purity) will also alter the culture parameters. We therefore recommend standardizing bone marrow antibody staining panels and FACS purification protocols for these cultures.

\section{Future perspectives}

Further improvement to the HSC expansion protocol is likely to be possible in the future, including improvements in long-term expansion of HSCs ex vivo ( $>2$ months) and the purity of the HSC cultures; at present only 1:34 cells are functional HSCs by day $28^{8}$. This will probably be achieved by further resolving HSCs with ex vivo self-renewal potential and by further optimizing the media conditions and protocol further. We envision that our simple culture condition will provide a useful platform on which to further build even better ex vivo HSC expansion conditions. For example, calcium concentrations have recently been suggested to play an important role in regulating HSC self-renewal ${ }^{25}$, and will be interesting to investigate within our culture conditions.

While we have shown that human HSCs can also be supported ex vivo within equivalent culture conditions in short-term (1-week) assays ${ }^{8}$, future work will also involve optimizing conditions for longer-term and larger-scale expansion of human HSCs. It is worth noting that while we have focused on developing protocols that start from purified mouse HSCs, protocols for human use generally start from bulk $\mathrm{CD} 34^{+}$hematopoietic stem and progenitor cells and may require protocol modification to accommodate this difference in starting cell type. It may also be possible to use similar conditions to improve the generation and expansion of HSCs derived from the in vitro differentiation of pluripotent stem cells ${ }^{26-28}$.

A large amount of effort has gone into developing human HSC culture protocols. It will be interesting to understand how our albumin-free culture conditions synergize with current state-of-the-art human $\mathrm{CD} 34^{+}$expansion cultures, such as batch-fed methods and those using the small molecules UM171 and SR $1^{29,30}$. We expect that the use of albumin-free conditions will synergize with these alternative culture methods. Indeed, use of complete media changes and noninflammatory PVA in our protocol appears to decrease the secretion of a similar set of cytokines/chemokines that the batch-fed method was designed to reduce ${ }^{8,31}$. It will also be worth considering whether media changes can be automated to improve reproducibility. PVA is inexpensive, chemically-defined, and Good Manufacturing Practice (GMP)-compatible, which will be important when considering future clinical translation.

The development of stable expansion culture conditions for human HSCs will have important implications for both experimental and clinical hematology. In particular, it will open up $\mathrm{HSCT}^{6}$ and associated gene therapies for wider, safer, and more flexible use. 
Ultimately, we hope that we will be able to use these conditions to generate enough human HSCs for nonconditioned HSCT as a non-toxic method to reconstitute the blood system, analogous to our proof-of-concept demonstration in mouse ${ }^{8}$. With conditions that stably grow HSCs, we envision that transplantation via multiple injections of HSCs, as performed in our mouse model $^{8}$, will be feasible. Such conditions will also greatly improve options for HSCT-related gene therapies including recent exciting applications of CRISPR/Cas9 gene editing technology ${ }^{32,33}$, which currently only have a very limited window of ex vivo modification.

\section{MATERIALS}

REAGENTS

Experimental animals-CAUTION: All experiments involving experimental animals should be performed in accordance with relevant national and institutional regulations, and within dedicated experimental animal facilities. All experimental data displayed here were generated in compliance with the Animal Care and Use Committee of the Institute of Medical Science University of Tokyo, and/or the Administrative Panel on Laboratory Animal Care at Stanford University. Please follow institutional guidelines related to the purchase, housing, and breeding of experimental mice.

- $\quad$ B6.SJL-Ptprca Pepcb/BoyJ (C57BL/6-CD45.1) mice, purchased from Jackson Laboratory (002014) or similar, or bred in-house (RRID:IMSR_JAX:002014). We recommend using 8-12-week old mice.

- $\quad$ C57BL/6 (C57BL/6-CD45.2) mice, purchased from Jackson Laboratory (000664) or similar, or bred in-house (RRID:IMSR_JAX:000664). We recommend using 8-12-week old mice.

- $\quad$ C57BL/6-Ptprc ${ }^{\mathrm{a}} / \mathrm{Ptprc}^{\mathrm{b}}$ (C57BL/6-CD45.1/CD45.2) mice, purchased or bred inhouse by breeding C57BL/6-CD45.1 mice with C57BL/6-CD45.2 mice. We recommend using 8-12-week old mice.

CAUTION: It will take at least three months to generate mice by in-house breeding and litter sizes may vary. Generation of competitor and recipient mice should be timed in order to ensure enough are available for transplantation assays.

\section{FACS and flow cytometry reagents}

- $\quad$ Biotin anti-mouse CD4 antibody, clone RM4-5 (eBioscience Cat\# 13-0042-85, RRID:AB_466330)

- Biotin anti-mouse CD8 antibody, clone 53-6.7 (eBioscience Cat\# 13-0081-86, RRID:AB_466348)

- Biotin anti-mouse CD45R/B220 antibody, clone RA3-6B2 (eBioscience Cat\# 13-0452-85, RRID:AB_466450)

- $\quad$ Biotin anti-mouse TER-119 antibody, clone TER-119 (eBioscience Cat\# 135921-85, RRID:AB_466798) 
- $\quad$ Biotin anti-mouse Gr-1/Ly-6G antibody, clone RB6-8C5 (eBioscience Cat\# 135931-85, RRID: AB_466801)

- $\quad$ Biotin anti-mouse CD127 antibody, clone A7R34 (eBioscience Cat\# 131271-85, RRID: AB_466589)

- $\quad$ Biotin anti-mouse FceR1 antibody, clone MAR-1 (eBioscience Cat\# 135898-82, RRID:AB_466783)

- $\quad$ APC/eFluor780 Streptavidin (eBioscience Cat\# 47-4317-82, RRID: AB_10366688)

- $\quad$ APC anti-mouse c-Kit antibody, clone 2B8 (eBioscience Cat\# 17-1171-83, RRID:AB_469431)

- $\quad$ PE anti-mouse Sca-1/Ly-6A/E antibody, clone D7 (BioLegend Cat\# 122508, RRID: AB_756193)

- PE/Cy7 anti-mouse CD150 antibody, clone TC15-12F12.2 (Biolegend Cat\# 115914, RRID: AB_439797)

- $\quad$ FITC anti-mouse CD34 antibody, clone RAM34 (eBioscience Cat\# 11-0341-85, RRID: AB_465022)

- $\quad \mathrm{PE} / \mathrm{Cy} 7$ anti-mouse CD45.1 antibody, clone A20 (Biolegend Cat\# 110730, AB_1134168; TONBO Biosciences Cat\# 60-0453, RRID:AB_2621850)

- $\quad$ BrilliantViolet421 (BV421) anti-mouse CD45.2 antibody, clone 104 (Biolegend Cat\# 109832, RRID:AB_2565511) or eFluor450 anti-mouse CD45.2 antibody, clone 104 (eBioscience Cat\# 48-0454-82, RRID: AB_11042125)

- $\quad$ PE anti-mouse CD11b antibody, clone M1/M7 (eBiosciences Cat\# 12-0112-82, RRID: AB_2734869)

- $\quad$ PE anti-mouse Gr1/Ly-6G antibody, clone RB6-8C5 (eBioscience Cat\# 125931-82, RRID: AB_466045)

- $\quad$ APC anti-mouse CD4 antibody, clone RM4-5 (eBioscience Cat\# 17-0042-83; RRID:AB_469324)

- $\quad$ APC anti-mouse CD8 antibody, clone 53-6.7 (eBioscience 17-0081-83. RRID: AB_469336)

- $\quad$ APC/eFluor780 anti-mouse CD45R/B220 antibody, clone RA3-6B2 (eBioscence 47-0452-82, RRID: AB_1518810)

- $\quad$ Propidium iodide (PI) solution (Biolegend Cat\# 421301)

- $\quad$ Sterile phosphate-buffered saline (PBS) (Gibco Cat\# 10010-023)

\section{Media reagents}

- 1X Ham's F-12 Nutrient Mix liquid media (Gibco Cat\# 11765-054 or Wako Cat\# 087-08335). Alternatively, HemEX-Type9A basal media (NIPRO Cat\# 87476) can be used, which already contains PVA. 
CAUTION: Once opened, F-12 media expires within 3 months. Do not use F-12 if the pH increases. This can be observed by the changing color of the phenol red color from red to pink.

- 1 M HEPES (Gibco Cat\# 15630-080)

- 100X Penicillin-Streptomycin-Glutamine (P/S/G) (Gibco Cat\# 10378-016)

- $\quad$ 100X Insulin-Transferrin-Selenium-ethanolamine (ITS-X) (Gibco Cat\# 51500056)

- $\quad$ Recombinant animal-free murine thrombopoietin (TPO) (Peprotech Cat\# AF-315-14)

- $\quad$ Recombinant animal-free murine stem cell factor (SCF) (Peprotech Cat\# AF-250-03)

- $\quad$ 87-90\%-hydrolyzed polyvinyl alcohol (PVA) (Sigma Cat\# P8136)

- $\quad$ Sterile deionized (DI) water (Gibco Cat\# 15230-162)

\section{Consumables}

- $\quad$ Sterile 96-well flat-bottom fibronectin-coated plates (Corning Cat\# 354409)

- $\quad$ Sterile 24-well flat-bottom fibronectin-coated plates (Corning Cat\# 354411)

CAUTION: Cell culture plates pre-coated with fibronectin typically expiry three months after arrival and must be kept at $4^{\circ} \mathrm{C}$ until use. Check expiry details with vendor.

- $\quad$ Sterile MACS LS column (Miltenyi Cat\# 130-042-401)

- $\quad$ Sterile $50 \mathrm{ml}$ Falcon conical tubes (Fisher Scientific Cat\# 352070)

- $\quad$ Sterile $15 \mathrm{ml}$ Falcon conical tubes (Fisher Scientific Cat\# 352096)

- $\quad$ Sterile $1.5 \mathrm{ml}$ microtubes (Axygen Cat\# MCT-150-C-S)

- $\quad$ FACS tubes with cell strainer (Corning Cat\# 352235)

- $\quad 100 \mu \mathrm{m}$ filter (Fisher Scientific Cat\# 22363549)

- $\quad 50 \mu \mathrm{m}$ CellTrics filter (Sysmex Partec 04-0042-2317)

- $\quad$ Sterile reagent reservoirs (Watson Cat\# 476-050S)

- $\quad$ Sterile $5 \mathrm{ml}$ syringe (TERUMO Cat\# SS-05SZ)

- $\quad$ Sterile 18-gauge needles (TERUMO Cat\# SS-1838R)

- $\quad$ Sterile 25-gauge needles (TERUMO Cat\# NN-2525R)

- $\quad$ Sterile $1 \mathrm{ml}$ syringe with 27-gauge needle (TERUMO Cat\# SS-10M2713A)

- Heparin-coated glass capillaries for blood collection (Hirschmann Cat\# 9100275) 


\section{Other reagents}

- $\quad$ Sterile deionized (DI) water

- $\quad$ Sterile tissue culture-grade PI water (Fisher Scientific Cat\# A12873-01)

- $\quad 70 \% \mathrm{vol} / \mathrm{vol}$ ethanol (30\% vol/vol DI water)

CAUTION: Ethanol is highly-flammable. Safely store according to institutional guidelines.

- $\quad$ Kimtech wipes (Kimberly-Clark Cat\# 34155)

- $\quad$ Turk's solution (Wako Cat\# 279-09495)

- $\quad$ Trypan Blue solution 0.4\% (Gibco Cat\# 15250-061)

- $\quad$ Ammonium chloride (Sigma Cat\# 254134)

\section{EQUIPMENT}

- $\quad$ Mouse dissection kit; scissors, forceps, tissue forceps (e.g. FST Cat\# 91460-11, 91100-12, 91121-12)

- $\quad$ Mortar and pestle (e.g. Fisher Scientific Cat\# FB970K)

- $\quad$ MidiMACS Separator magnet and MACS multistand (Miltenyi Cat\# 130042-302, 130-042-303)

- Hemocytometer (e.g. Hausser Scientific Cat\# 02-671-51B)

- OPTIONAL: automated cell counter and counter slides (e.g. Chemometec Cat\# NC-3000)

- Laminar-flow sterile tissue culture hood (various vendors available)

- Laboratory vortex (e.g. Scientific Industries Vortex Genie-2 Cat\# SI-0236)

- $\quad$ Set of sterile pipettes (we recommend P1000, P200, P20, and P2 pipettes and a 12-well P200 multichannel pipette) and sterile filter tips (e.g. Gibson or equivalent)

- $\quad$ Sterile electric pipet-aid and associated sterile strip-pipettes (e.g. Gibson or equivalent)

- $\quad$ Laboratory scales (e.g. Mettler Toledo Cat\# ME103TE/00)

- $\quad$ Laboratory autoclave (e.g. Tomy SX-500 High-Pressure Steam Sterilizer)

- $\quad$ Laboratory waterbath capable of heating to $37^{\circ} \mathrm{C}$ (various vendors available)

- Tissue culture incubator, humified and set to $37^{\circ} \mathrm{C}$ with $5 \% \mathrm{CO}_{2}$ and $20 \% \mathrm{O}_{2}$ (e.g. Thermo Scientific HERACELL150i or equivalent)

- $\quad$ Fluorescence-activated cell sorter with 96-well plate sorting capacity (e.g. BD FACS AriaII Special Order, or equivalent; at minimum a six-color sorter)

CAUTION: FACS machines contain high-powered lasers that are dangerous when not used safely. Please follow all institutional and manufacturer safety procedures. 
CAUTION: Check the availability and procedures for accessing FACS machines within your laboratory/institution before starting this protocol. Many research institutions maintain FACS core facilities, but these may require training or advanced booking to access. Unless experienced with FACS, we recommend requesting a fully-trained FACS technician perform FACS sorting for you.

- OPTIONAL: For flow cytometric analysis of HSC cultures, peripheral blood, or bone marrow, a flow cytometer rather than FACS machine can be used (e.g. BD LSRFortessa or BD FACSCantoII; at minimum six color analyzer).

- $\quad$ FlowJo software (FlowJo, LLC)

- $\quad$ Light microscope for cell culture (e.g. NIKON ECLIPSE TS100)

- $\quad$ Laboratory centrifuge(s) for $1.5 \mathrm{ml}, 15 \mathrm{ml}$, and $50 \mathrm{ml}$ tubes (e.g. Eppendorf 5430R or equivalent)

CAUTION: Always ensure that your centrifuge is balanced while in use.

- $\quad$ Cabinet X-ray System (e.g. Faxitron 43855F or Hitachi NBR-1520R)

CAUTION: All institutional, state, and/or national regulations need to be followed when using irradiators. Please ensure you are fully trained and fully compliant when using an irradiator.

CAUTION: Check the availability and procedures for accessing irradiators within your laboratory/institution before starting this protocol. Many research institutions maintain irradiators, but these may require training or advanced booking to access.

\section{REAGENT SET UP}

PVA solution-Make up a $100 \mathrm{mg} / \mathrm{ml}$ stock of PVA in tissue culture-grade DI water in a heatproof glass bottle and autoclave using standard settings to dissolve. Pre-heating the DI water before adding the PVA and autoclaving can help to completely dissolve the PVA. Make sure not to tighten the bottle lid while autoclaving. Aliquot in sterile tubes and stock at $4^{\circ} \mathrm{C}$ for up to 3 months.

CRITICAL STEP: PVA requires high heat to dissolve at $100 \mathrm{mg} / \mathrm{ml}$.

Cytokine stocks-Dissolve SCF and TPO cytokines at 1:1000 stocks in F-12 media (10 $\mu \mathrm{g} / \mathrm{ml}$ stock for SCF; $100 \mu \mathrm{g} / \mathrm{ml}$ stock for TPO). Aliquot in sterile tubes and stock long-term at $-20^{\circ} \mathrm{C}$ or $-80^{\circ} \mathrm{C}$. See manufacturer information regarding stability (usually $\sim 1$ year at $-80^{\circ} \mathrm{C}$ ). During use, aliquots can be stocked at $4^{\circ} \mathrm{C}$, but should be used within 1 week of thawing.

HSC media-Mix media reagents to make F12 media supplemented with $10 \mathrm{mM}$ HEPES, $1 \mathrm{X}$ P/S/G, 1 X ITSX, $1 \mathrm{mg} / \mathrm{ml}$ PVA, $100 \mathrm{ng} / \mathrm{ml}$ TPO, and $10 \mathrm{ng} / \mathrm{ml} \mathrm{SCF}$ (see Table below for an example recipe). Note that PVA solution is viscous and will need to be pipetted slowly. Mix media by inversion or vortexing and ensure the media is pre-warmed to $37^{\circ} \mathrm{C}$. We recommend aliquoting the desired volume of the F12 media and pre-warming it (typically for $\sim 15-30$ minutes to reach $37^{\circ} \mathrm{C}$ ) rather than repeatedly warming and cooling your F12 
media stock bottle. Typically, $200 \mu \mathrm{l}$ media is used per 96-well plate well or $1 \mathrm{ml}$ media per 24-well plate well. Unless cell cultures are being passaged, there is no need to transfer cells into fresh wells during media changes.

CRITICAL STEP: Make HSC media fresh for every use.

HSC media mix (to make a total of $1 \mathrm{ml}$ )

\begin{tabular}{|l|l|l|}
\hline Reagent & Volume $(\boldsymbol{\mu l})$ & Final concentration in F-12 \\
\hline F-12 media & 958 & N/A \\
\hline $100 X \mathrm{P} / \mathrm{S} / \mathrm{G}$ & 10 & $1 \mathrm{X}$ \\
\hline $1 \mathrm{M} \mathrm{HEPES}$ & 10 & $10 \mathrm{mM}$ \\
\hline $100 \mathrm{mg} / \mathrm{ml}$ PVA stock & 10 & $1 \mathrm{mg} / \mathrm{ml}$ \\
\hline $100 \mathrm{X}$ ITSX & 10 & $1 \mathrm{X}$ \\
\hline $100 \mu \mathrm{g} / \mathrm{ml}$ TPO stock & 1 & $100 \mathrm{ng} / \mathrm{ml}$ \\
\hline $10 \mu \mathrm{g} / \mathrm{ml} \mathrm{SCF}$ stock & 1 & $10 \mathrm{ng} / \mathrm{ml}$ \\
\hline
\end{tabular}

Biotin-conjugated lineage antibody master mix - Mix together biotin-Gr1/Ly-6G, biotin-Ter119, bioin-CD4, biotin-CD8, biotin-CD45R/B200, and biotin-CD127 antibodies in sterile PBS. See Table below for an example recipe (we recommend titrating the volume of each antibody before use). Stock at $4^{\circ} \mathrm{C}$ and use within 3 months. We typically use $3 \mu \mathrm{l}$ master mix per $10^{7}$ cells.

RECOMMENDED: While not a standard antibody in mouse lineage antibody cocktails for HSC analysis, we recommend adding biotin-FceR1 antibody because $\mathrm{FceR} 1^{+}$cells (likely mast cell progenitors) can expand within the cultures.

Example biotin-conjugated lineage antibody master mix

\begin{tabular}{|l|l|}
\hline Reagent & Volume $(\boldsymbol{\mu l})$ \\
\hline Biotin-Gr1/Ly-6G $(0.5 \mathrm{mg} / \mathrm{mL})$ & 100 \\
\hline Biotin-Ter119 $(0.5 \mathrm{ml} / \mathrm{mL})$ & 100 \\
\hline Biotin-CD4 $(0.5 \mathrm{mg} / \mathrm{mL})$ & 25 \\
\hline Biotin-CD8 $(0.5 \mathrm{mg} / \mathrm{mL})$ & 25 \\
\hline Biotin-CD45R/B220 $(0.5 \mathrm{mg} / \mathrm{mL})$ & 50 \\
\hline Biotin-CD127 $(0.5 \mathrm{mg} / \mathrm{mL})$ & 50 \\
\hline Sterile PBS & 350 \\
\hline
\end{tabular}

Kit-enriched bone marrow HSC antibody stain-Mix together FITC-CD34, APC-cKit, PE-Sca1, APC/eFluor780-Streptavidin, and PE/Cy7-CD150 antibodies in PBS. Make fresh for each experiment and protect from direct light. See Table below for an example recipe (we recommend titrating the volume of each antibody before use). Add $400 \mu \mathrm{l}$ per $1 \times 10^{7}$ cells (scale based on cell number). 
Example antibody stain for 10 million c-Kit-enriched bone marrow cells

\begin{tabular}{|l|l|}
\hline Reagent & Volume $(\boldsymbol{\mu l})$ \\
\hline FITC-CD34 $(0.5 \mathrm{mg} / \mathrm{mL})$ & 4 \\
\hline APC-c-Kit $(0.2 \mathrm{mg} / \mathrm{mL})$ & 1 \\
\hline PE-Sca1 $(0.2 \mathrm{mg} / \mathrm{mL})$ & 1 \\
\hline APC/eFluor780-Streptavidin $(0.2 \mathrm{mg} / \mathrm{mL})$ & 1 \\
\hline PE/Cy7-CD150 $(0.2 \mathrm{mg} / \mathrm{mL})$ & 1 \\
\hline Sterile PBS & 392 \\
\hline
\end{tabular}

Cultured HSC antibody stain-Mix together APC-c-Kit, PE-Sca1, APC/eFluor780Streptavidin, and PE/Cy7-CD150 antibodies in PBS. Make fresh for each experiment and protect from direct light. See Table below for an example recipe (we recommend titrating the volume of each antibody before use). Add $400 \mu \mathrm{l}$ per $1 \times 10^{6}$ cells (scale based on cell number).

Example cultured HSC antibody stain for 10 samples ( $<50,000$ cell/sample)

\begin{tabular}{|l|l|}
\hline Reagent & Volume $(\boldsymbol{\mu l})$ \\
\hline APC-c-Kit $(0.2 \mathrm{mg} / \mathrm{mL})$ & 1 \\
\hline PE-Sca1 $(0.2 \mathrm{mg} / \mathrm{mL})$ & 1 \\
\hline APC/eFluor $780-$ Streptavidin $(0.2 \mathrm{mg} / \mathrm{mL})$ & 1 \\
\hline PE/Cy7-CD150 $(0.2 \mathrm{mg} / \mathrm{mL})$ & 1 \\
\hline Sterile PBS & 396 \\
\hline
\end{tabular}

Peripheral blood antibody stain-Mix together PE-CD11b, PE-Gr1/Ly-6G, APC-CD4, APC-CD8, APC/eFluor780-CD45R/B220, PE/Cy7-CD45.1, and BV421-CD45.2 antibodies in PBS. Make fresh for each experiment and protect from direct light. See Table below for an example recipe (we recommend titrating the volume of each antibody before use). Use $100 \mu \mathrm{l}$ antibody stain per sample.

Example peripheral blood antibody stain for 20 samples

\begin{tabular}{|l|l|}
\hline Reagent & Volume $(\boldsymbol{\mu l})$ \\
\hline PE-CD11b $(0.2 \mathrm{mg} / \mathrm{mL})$ & 1 \\
\hline PE-Gr1/Ly-6G $(0.2 \mathrm{mg} / \mathrm{mL})$ & 1 \\
\hline APC-CD4 $(0.2 \mathrm{mg} / \mathrm{mL})$ & 1 \\
\hline APC-CD8 $(0.2 \mathrm{mg} / \mathrm{mL})$ & 1 \\
\hline APC/eFluor780-CD45R/B220 $(0.2 \mathrm{mg} / \mathrm{mL})$ & 2 \\
\hline PE/Cy7-CD45.1 $(0.2 \mathrm{mg} / \mathrm{mL})$ & 4 \\
\hline BV421-CD45.2 or eFluor-CD45.2 $(0.2 \mathrm{mg} / \mathrm{mL})$ & 4 \\
\hline
\end{tabular}




\begin{tabular}{|l|l|}
\hline Reagent & Volume $(\mu \mathbf{l})$ \\
\hline Sterile PBS & 1986 \\
\hline
\end{tabular}

Bone marrow engraftment antibody stain-Mix together FITC-CD34, APC-c-Kit, PE-Sca1, APC/eFluor780-Streptavidin, PE/Cy7-CD45.1, and BV421-CD45.2 antibodies in PBS. Make fresh for each experiment and protect from direct light. See Table below for an example recipe (we recommend titrating the volume of each antibody before use). Add 400 $\mu \mathrm{l}$ per $10^{7}$ cells (scale based on cell number).

Example bone marrow engraftment antibody stain for 10 million whole bone marrow cells

\begin{tabular}{|l|l|}
\hline Reagent & Volume $(\boldsymbol{\mu l})$ \\
\hline FITC-CD34 $(0.5 \mathrm{mg} / \mathrm{mL})$ & 4 \\
\hline APC-c-Kit $(0.2 \mathrm{mg} / \mathrm{mL})$ & 1 \\
\hline PE-Sca1 $(0.2 \mathrm{mg} / \mathrm{mL})$ & 1 \\
\hline APC/eFluor780-Streptavidin $(0.2 \mathrm{mg} / \mathrm{mL})$ & 1 \\
\hline PE/Cy7-CD45.1 $(0.2 \mathrm{mg} / \mathrm{mL})$ & 3 \\
\hline BV421-CD45.2 $(0.2 \mathrm{mg} / \mathrm{mL})$ & 3 \\
\hline Sterile PBS & 387 \\
\hline
\end{tabular}

FACS buffer-Add PI solution to sterile PBS at 1:1000 vol/vol. Stock at $4{ }^{\circ} \mathrm{C}$, protected from the light until use, for up to 1 month.

Red Cell Lysis buffer-Dissolve ammonium chloride in sterile DI water at a concentration of $8.4 \mathrm{~g} / \mathrm{L}$. Store at room temperature until use, for up to 3 months.

\section{Procedure}

Collecting mouse HSCs_CRITICAL: Keep all bone marrow cells on ice as much as possible throughout the collection process.

Step 1. Spray dissection kit, bench area, and mortar and pestle with $70 \%$ ethanol to sterilize. Allow ethanol to evaporate. Wash mortar and pestle with $5 \mathrm{ml}$ PBS before use.

Step 2. Humanely euthanize donor mice, for example using $\mathrm{CO}_{2}$ asphyxiation followed by cervical dislocation. We recommend using 8-12-week old mice as donors.

CAUTION: Mice euthanasia should be performed in accordance with institutional and national regulations and following appropriate training.

Step 3. Spray euthanized mice with $70 \%$ ethanol to sterilize the skin and stick down the fur. Dissect out femurs, tibias, and pelves from euthanized mice and place in a dish containing PBS. Remove attached muscle by cleaning bones with Kimtech wipes and place in a pestle containing $5 \mathrm{ml}$ PBS.

Nat Protoc. Author manuscript; available in PMC 2021 February 01. 
Step 4. Crush bones by tapping with the mortar to release the bone marrow. After 1-2 minutes, clean the mortar with 1-2 ml PBS. Place mortar on a sterile surface. Use a 5 $\mathrm{ml}$ syringe with an 18-gauge needle to disrupt any clumps of bone marrow and to wash the walls of the pestle. Collect the single cell PBS suspension and filter through a $100 \mu \mathrm{m}$ filter into a $50 \mathrm{ml}$ tube.

CRITICAL STEP: Do not grind bones with mortar and pestle to avoid excessive cell damage. CAUTION: Be careful with sharp needles. Do not re-sheath. Dispose safely according to institutional guidelines.

Step 5. Add $5 \mathrm{ml}$ of fresh PBS and repeat step 4 until the bones have turned almost white colored. Typically, this is reached after a total of four rounds of tapping and washing. Once all bone marrow has been collected in the $50 \mathrm{ml}$ tube, centrifuge at $440 \mathrm{~g}$ for 5 minutes at $4^{\circ} \mathrm{C}$. Remove the supernatant (this can be kept to provide cells for the single cell controls).

Step 6. Disrupt the cell pellet by flicking the tube 2-4 times. Resuspend the cells in 5 $\mathrm{ml}$ PBS and transfer through a $50 \mu \mathrm{m}$ filter into a sterile $15 \mathrm{ml}$ tube. Wash the $50 \mathrm{ml}$ tube with a second $5 \mathrm{ml}$ PBS and transfer through the same filter into the same $15 \mathrm{ml}$ tube. Invert the $15 \mathrm{ml}$ tube several times to generate a homogenous solution and then collect $10 \mu \mathrm{l}$ for cell counting. Centrifuge the remaining cells at $440 \mathrm{~g}$ for 5 minutes at $4^{\circ} \mathrm{C}$.

Step 7. Count the cells using a hemocytometer. We recommend diluting the $10 \mu \mathrm{l}$ cells 1:10-1:20 vol/vol in Turk's solution to achieve a cell concentration that can be accurately counted.

Step 8. Remove the supernatant from the $15 \mathrm{ml}$ tube, disrupt the cell pellet by flicking, and resuspend the cells in 250-500 $\mu \mathrm{PBS}$ and add APC-c-Kit antibody. We typically use $0.2 \mu$ APC-c-Kit antibody per $1 \times 10^{7}$ cells (all antibodies should be titrated before use). Mix by flicking, and incubate for 30 minutes at $4{ }^{\circ} \mathrm{C}$, protected from the light.

Step 9. Add $5 \mathrm{ml}$ PBS to the cells and transfer into a fresh $15 \mathrm{ml}$ tube through a 50 $\mu \mathrm{m}$ filter. Wash the first $15 \mathrm{ml}$ tube with $8 \mathrm{ml}$ PBS and transfer to the new $15 \mathrm{ml}$ tube via the same filter. Centrifuge at $440 \mathrm{~g}$ for 5 minutes at $4^{\circ} \mathrm{C}$. Remove the supernatant from the $15 \mathrm{ml}$ tube, disrupt the cell pellet by flicking, and resuspend the cells in 250-500 $\mu \mathrm{l}$ PBS and add anti-APC microbeads. We typically use $0.2 \mu \mathrm{l}$ microbeads per $1 \times 10^{7}$ cells (antibodies should be titrated before use). Mix by flicking, and incubate for 15 minutes at $4^{\circ} \mathrm{C}$, protected from the light..

Step 10. Add $13 \mathrm{ml}$ PBS and centrifuge at $440 \mathrm{~g}$ for 5 minutes at $4^{\circ} \mathrm{C}$. Remove the supernatant, disrupt the cell pellet by flicking, and resuspend in $2 \mathrm{ml}$ PBS. During the centrifugation step, prepare a Miltenyi LS MACS column by placing the LS column into a MidiMACS Separator magnet, a $50 \mu \mathrm{m}$ filter on top, and a $15 \mathrm{ml}$ waste tube below. Prewet the filter and LS column with 3-5 ml PBS. Allow PBS to completely drain through by gravity before proceeding to the next step.

CRITICAL STEP: Ensure that the collection tube is not touching the LS column to avoid drawing the cell suspension through the LS column. 
Step 11. Using a P1000 pipette, gently transfer all $2 \mathrm{ml}$ of cells to the same filter and allow to completely drain through the LS column by gravity.

Step 12. Wash the $15 \mathrm{ml}$ tube with $3 \mathrm{ml}$ PBS and then transfer to the LS column via the same filter. Again, allow to completely drain through by gravity. Repeat this wash step, then remove the filter. Perform a third wash of the LS column by gently applying $3 \mathrm{ml}$ of fresh PBS. Allow to completely drain by gravity.

Step 13. Remove the LS column from the magnet and place on a fresh $15 \mathrm{ml}$ tube. Add $5 \mathrm{ml} \mathrm{PBS}$ and gently eject into the tube using the plunger provided with the LS column. Remove the plunger and repeat the elution using a second $5 \mathrm{ml}$ of PBS. The LS column can then be discarded.

Step 14. Mix the eluted cell suspension by inverting several times, then remove $10 \mu \mathrm{l}$ for cell counting. Centrifuge the remaining cells at $440 \mathrm{~g}$ for 5 minutes at $4^{\circ} \mathrm{C}$. While the cells are centrifuging, count the cells with a hemocytometer. We recommend diluting the cells 1:2 vol/vol with Turks solution for counting.

Step 15. Remove the supernatant from the cells (the cell pellet will now be much smaller), disrupt by flicking the tube, and resuspend in 100-400 $\mu$ l PBS. Add the $3 \mu \mathrm{l}$ per $1 \times 10^{7}$ cells of the biotin-conjugated lineage antibody master mix and incubate for 30 minutes at $4^{\circ} \mathrm{C}$, protected from the light.

Step 16. Add $13 \mathrm{ml}$ of PBS to the tube and centrifuge at $440 \mathrm{~g}$ for 5 minutes at $4{ }^{\circ} \mathrm{C}$ (there is no need to filter at this point). Remove the supernatant from the cells, disrupt by flicking the tube, and resuspend in the c-Kit enriched bone marrow HSC antibody stain at a ratio of $400 \mu \mathrm{l}$ per $1 \times 10^{7}$ cells. Incubate for 90 minutes at $4^{\circ} \mathrm{C}$ in the dark. Keep the cell suspended in the antibody/PBS mixture by gently flicking the tube every 15-20 minutes.

CRITICAL STEP: The RAM34 clone anti-CD34 antibody requires a 90-minute incubation at $4{ }^{\circ} \mathrm{C}$. During the antibody incubation, the HSC media and plates can be prepared as described in the next step.

Step 17. Make the $\boldsymbol{H S C}$ media and transfer $200 \mu$ media per 96-well plate well, or 1 $\mathrm{ml}$ per 24-well plate well into fibronectin-coated plate wells. Unstained and single cell controls should also be prepared and the FACS machine readied for HSC sorting.

CRITICAL STEP: For long-term expansion cultures, use fibronectin-coated plate wells to improve the retention of HSCs during media changes and maximize expansion during the culture.

CRITICAL STEP: Do not plan to culture HSCs in the outer-most wells of the plate (although this may not be possible if you need to perform many cultures in parallel, e.g. for clonal cultures). Instead, fill the outer-most wells of the plate with $200 \mu \mathrm{l}$ PBS and use the inner wells for HSC cultures. Also fill any unused plate wells with PBS.

Step 18. Add $13 \mathrm{ml}$ of PBS to the tube of cKit-enriched cells and centrifuge at $440 \mathrm{~g}$ for 5 minutes at $4{ }^{\circ} \mathrm{C}$. Remove the PBS, flick the tube to disrupt the cell pellet and resuspend the cells in FACS buffer at a ratio of $1 \mathrm{ml}$ per $10^{7}$ cells. FACS purify 
$\mathrm{CD} 150^{+} \mathrm{CD} 34^{-/ / \mathrm{lo}} \mathrm{Kit}^{+} \mathrm{Sca} 1^{\mathrm{hi}} \mathrm{Lin}^{-}$cells directly into appropriate plate wells containing HSC media. See the example gating scheme for HSC sorting in Figure 2.

CRITICAL STEP: We recommend that long-term HSC cultures are initiated from $\mathrm{CD} 150^{+} \mathrm{CD} 34^{-/ / \mathrm{lo}} \mathrm{Kit}^{+} \mathrm{Sca} 1{ }^{\mathrm{hi}} \mathrm{Lin}^{-}$cultures to enrich your starting culture with self-renewing HSCs, particularly when performing clonal expansion. Cultures can be initiated from $\mathrm{CD} 34^{-/ / \mathrm{lo}} \mathrm{Kit}^{+} \mathrm{Sca} 1^{\mathrm{hi}} \mathrm{Lin}^{-}$or $\mathrm{Kit}^{+} \mathrm{Sca}{ }^{+}{ }^{+} \mathrm{Lin}^{-}$bone marrow cells but cultures may display more heterogeneity and/or reduced HSC frequency.

CRITICAL STEP: High-purity cell sorting should be determined by flow cytometric analysis of sorted cells (use test cells sorted into a spare well). For clonal culture of mouse $\boldsymbol{H S C}$, we recommend using the single cell sorting mode and performed using Index Mode so that the phenotype of cell sorted can be confirmed (and that only one cell was sorted).

\section{Culture of HSC}

Step 19. Follow option A for bulk culture or option B for clonal cell culture.

\section{Option A: Bulk culture of mouse HSCs}

i) After sorting, immediately place culture plate in a sterile and humidified tissue culture $37^{\circ} \mathrm{C}$ incubator with $5 \% \mathrm{CO}_{2}$ and $20 \% \mathrm{O}_{2}$. Bulk HSC cultures are typically initiated from 50 cells in a 96-well plate well. However, larger numbers of cells can be sorted per well e.g. 100-1000 cells for a 96-well plate well containing $200 \mu \mathrm{l}$ media or up to 5,000 cells into a 24-well plate well containing $1 \mathrm{ml}$ of media. Check the cell cultures visually every couple of days by light microscopy, although minimize the time plates are removed from the incubator (preferably $<5$ minutes). Cells should be small and bright, and gradually expand over the well. although some larger cells are expected, By contrast, excessive cell death or clumping often signifies poor culture stability. See Figure 3 for example microscopy images.

CAUTION: As cells are sorted into the wells within a droplet of FACS sheath fluid, the HSC media will become increasingly diluted with sheath fluid, which can reduce the culture stability. Where possible, sort no more than 500 cells per $200 \mu \mathrm{l}$ media. If higher numbers are required, consider performing a half-media change after 2 days.

Ii) Initiate complete media changes from day 5 onwards. For 96-well plate wells, use a P200 pipette (or for a 24-well plate use a P1000 pipette) to gradually remove media from near the meniscus, gradually moving the pipette tip down the side of the well. Remove media until the meniscus of the media is at the bottom of the well and essentially all media is removed. See Video 1 and Video 2 for visual examples of how to do this.

CRITICAL STEP: Removing 100\% of the media will result in loss of cells. Aim to remove $\sim 95 \%$ of the media. To avoid cells drying out during media changes, do not remove media from more than 5 wells at a time.

Iii) As soon as possible, add $200 \mu \mathrm{l}$ (for 96-well plate wells, $1 \mathrm{ml}$ for 24-well plate wells) of pre-warmed and freshly-prepared $\mathrm{HSC}$ media to each well, by gently 
dribbling the media down the side of the well. During media changes, try to remove and add media from the same side of the well so as to minimize disturbing the cells monolayer that forms on the base of the well. See Video 1 and Video 2 for details.

Iv) Perform media changes every 2-3 days throughout the remaining culture. Cultures derived from 50 fresh HSCs generally require passaging after 3-4 weeks, once the culture reaches over $90 \%$ confluency. One 96-well plate well should be split into three 96 -well plates wells or one 24 -well plate well.

\section{Option B: Clonal culture of mouse HSCs}

I) Initiate clonal HSCs culture by sorting 1 cell per well in 96 well plate wells. Due to the clonal heterogeneity of HSCs, we recommend testing at least 48 cells per condition (preferably 96 cells, i.e. an entire plate per condition). Using $\mathrm{CD} 150^{+} \mathrm{CD} 34^{-/ l o} \mathrm{Kit}^{+} \mathrm{Sca} 1{ }^{\text {hi }} \mathrm{Lin}^{-}$cells, $>90 \%$ colony formation should be achievable. After sorting, immediately place culture plate in a sterile and humidified tissue culture $37^{\circ} \mathrm{C}$ incubator with $5 \% \mathrm{CO}_{2}$ and $20 \% \mathrm{O}_{2}$.

CAUTION: Single cell sorting accuracy can be assessed by light microscopy 24 hours after sorting. However, single cell in a 96 well plate can be difficult to find within the well. After 5-7 days, small clusters of cells should appear that are easier to identify. Do not remove the plate from the incubator for more than $\sim 5$ minutes at a time to avoid disturbing the culture.

Ii) Initiate complete media changes from day 7-10 onwards. Due to the number of wells that are required media changes, we recommend using a multi-channel pipette for this step. Gradually remove media from near the meniscus, simultaneously moving the pipette tip down the side of the well. Remove media until meniscus of the media is at the bottom of the well and essentially all media is removed.

CRITICAL STEP: When removing media with a multichannel pipette, it is very important for the pipette to be level with the plate so that media is equally removed from each well (and from the same position within the well. To avoid cells drying out during media changes, we do not recommend removing media from more than half a plate at a time.

Iii) Transfer pre-warmed and freshly-prepared $\boldsymbol{H S C}$ media to a media reservoir. As soon as possible, add $200 \mu \mathrm{l}$ of $\boldsymbol{H S C}$ media to each well using a multi-channel pipette, by gently dribbling the media down the side of the well. During media changes, try to remove and add media from the same side of the well so as to minimize disturbing the cells monolayer that forms on the base of the well.

Iv) Perform media changes every 2-3 days throughout the remaining culture.

\section{In vitro analysis of HSC cultures}

Step 20. Count cell cultures at any point during the culture. To do this, dissociate the cells by gently pipetting and then transfer $10 \mu \mathrm{l}$ of the culture to a tube. Count with a hemocytometer or automated cell counter. Use a dead cell stain (e.g. Trypan Blue) to accurately count live cells. If cultures are at low density, it may be necessary to first 
remove $50-75 \%$ of the media from the well (without disturbing the cells), and then mix and count the cells in the smaller volume.

CAUTION: It is not recommended to repeatedly mix the HSC cultures. At least for bulk cultures, it is preferable to have independent cultures that are analyzed at different time points.

Step 21. At desired timepoints monitor the stability of HSC cultures by flow cytometric analysis. To do this, first collect cells from culture at the desired timepoint by gently washing the plate bottom to dissociate the HSCs. We recommend aiming to collect $\sim 20,000$ cells (up to 50,000 cells) for analysis. For cultures initiated from 50 HSCs, this represents the entire well of a day 7 culture, or $\sim 10 \%$ of a day 28 culture.

CRITICAL STEP: On fibronectin coated plates, HSCs are only lightly attached to the plate bottom. Gentle washing of the plate bottom with the culture media using a pipette is sufficient to lift the HSCs. Aggressive mixing may reduce cell viability. Where possible, we recommend performing media changes on different days to this: resuspension of cells in fresh media may reduce c-Kit expression levels.

Step 22. Stain up to 50,000 cells with $0.1 \mu \mathrm{l}$ biotin-conjugated lineage antibody master mix in $40 \mu \mathrm{l}$ PBS for 30 minutes at $4{ }^{\circ} \mathrm{C}$.

Step 23. Wash with $1 \mathrm{ml} \mathrm{PBS}$ and centrifuge at $440 \mathrm{~g}$ for 5 minutes at $4^{\circ} \mathrm{C}$. Resuspend the cells with $40 \mu \mathrm{l}$ of freshly-prepared cultured HSC antibody stain for 30 minutes at $4^{\circ} \mathrm{C}$ in the dark.

Step 24. Wash with $1 \mathrm{ml}$ PBS and spin down at $440 \mathrm{~g}$ for 5 minutes at $4^{\circ} \mathrm{C}$.

Resuspend in 100-200 $\mu \mathrm{l}$ FACS buffer. Analyze samples using a flow cytometer or FACS machine using appropriate control samples for gating. Aim to collect at least 10,000 live cells per sample. See the example gating scheme for HSC culture analysis in Figure 4. When analyzing clonally-derived HSCs, significant culture heterogeneity is expected, including both good and bad cultures; see Figure 5 for examples. Parameters for assessing cultures are indicated below:

\begin{tabular}{|l|l|l|}
\hline Parameter & Expected HSC cultures & Poor-quality cultures \\
\hline$\%$ of live cells & $>80 \%$ & $<70 \%$ \\
\hline$\% \mathrm{Lin}^{+}$cells in live gate & $<5 \%$ & $>10 \%$ \\
\hline$\% \mathrm{Kit}^{+} \mathrm{Sca} 1^{+}$in Lin- gate & $>30 \%$ & $<20 \%$ \\
\hline$\%$ of CD $150^{+}$in $\mathrm{KSL}$ gate & $>40 \%$ & $<20 \%$ \\
\hline
\end{tabular}

\section{Transplantation analysis}

Step 25. To transplant into nonconditioned recipients, follow option A. For competitive transplantation analysis in radiation-conditioned recipients follow option B.

Option A: Transplantation analysis in nonconditioned recipients: CAUTION: All animal procedures should be approved by your institution prior to initiating any experiments 
and performed in dedicated animal facilities. We recommend transplanting at least 5 mice/ condition or the required recipient numbers can be estimated using power analysis.

CRITICAL To avoid the potential for immunological rejection of donor cells, C57BL/ 6CD45.1/CD45.2 recipient mice are recommended for this assay when using C57BL/ 6CD45.1 donor-derived HSCs. We recommend using 8-12-week old mice as recipients. No pretransplantation conditioning of recipients is required.

I) Collect cultured CD45.1 donor cells of interest from the HSC cultures in up to $200 \mu \mathrm{l}$ media or PBS in a sterile $1.5 \mathrm{ml}$ tube and keep on ice. The total cell culture to be transplanted in a recipient should be split into three injections, for injection on three consecutive days (e.g. day 28, 29, and 30). If a fraction of the cells/media are removed from a culture well, an equal volume of pre-warmed and freshly-prepared HSC media should be added to replace the removed media volume.

CRITICAL STEP: Maximal levels of engraftment will only be seen if HSC cultures are split into multiple injections. We recommend transplanting 3 doses split over 3 consecutive days.

Ii) Transplant the donor cells into the recipient mice by retro-orbital or tail-vein injection using a $1 \mathrm{ml} 27$-gauge needle. Repeat transplantation on second and third day.

CAUTION: Ensure that all animal protocols have institutional approval before initiating these experiments. Ensure that appropriate analgesia is provided to the recipients as necessary. Monitor the mice following transplantation, particularly where analgesia is used, following all relevant guidelines.

Iii) Collect 50-100 $\mu \mathrm{l}$ of peripheral blood using a heparin-coated glass capillaries from recipient mice, using institutionally-approved protocols once every 4 weeks after transplantation, at least up until 16-weeks post-transplantation. Collect peripheral blood in a $1.5 \mathrm{ml}$ tube and then gently flick to ensure the blood is mixed.

CAUTION: Where analgesia is used, carefully monitor mouse during and following bleeding.

CRITICAL Follow the steps iv-vii each time you collect blood.

Iv) Add $1 \mathrm{ml}$ Red Cell Lysis buffer to each tube, mix by inversion, and incubate for 15 minutes at room temperature. Centrifuge blood at $440 \mathrm{~g}$ for 5 minutes at room temperature and then remove supernatant without disturbing the cell pellet.

CRITICAL STEP: The pellet of mononuclear cells after centrifugation will be loose. Leave $\sim 100 \mu \mathrm{l}$ liquid in the tube to avoid losing cells.

V) Add $1 \mathrm{ml}$ of fresh Red Cell Lysis buffer to each tube and incubate for 10-15 minutes at room temperature. Transfer through a $50 \mu \mathrm{m}$ filter into a FACS tube and add $1 \mathrm{ml}$ PBS. Keep $\sim 10 \%$ of each tube for unstained and single stain control samples. Centrifuge blood at $440 \mathrm{~g}$ for 5 minutes at room temperature. 
Vi) Carefully remove the supernatant without disrupting the cell pellet. Resuspend in $100 \mu \mathrm{l}$ of peripheral blood antibody stain, flick the tube to disrupt and mix the cells, and incubate for 30 minutes at $4^{\circ} \mathrm{C}$ in the dark. Divide up leftover sample for unstained and single stain control samples and add equivalent concentrations of antibody to each well.

Vii) Add $2 \mathrm{ml} \mathrm{PBS}$ per tube and centrifuge at $440 \mathrm{~g}$ for 5 minutes. Remove supernatant resuspend in $200 \mu \mathrm{l}$ FACS buffer and analyze samples using a FACS machine or flow cytometer, setting gating using unstained and single stained control samples. Aim to collect at least 10,000 live $\mathrm{CD} 45^{+}$cells per sample. See the example gating scheme for peripheral blood analysis in Figure 6.

Viii) At the end timepoint, perform bone marrow HSC analysis following institutionally-approved humane euthanasia of the recipient. The same HSC isolation protocol can be used as above (see the collecting mouse HSCs section), except that we recommend staining whole bone marrow cells (rather than c-Kit enriched cells) with the biotin-conjugated lineage antibody master mix and bone marrow engraftment stain. Aim to collect at least 100,000 Lineage- cells per sample. See the example gating scheme for bone marrow HSC chimerism analysis in Figure 7.

Option B: Competitive transplantation analysis in irradiated recipients: CAUTION: All animal procedures should be approved by your institution prior to initiating any experiments. We recommend transplanting at least 5 mice/condition but required recipient numbers can be estimated using power analysis.

I) Irradiate recipient mice according to national and institutional regulations. We recommend splitting the irradiation into two equal doses, separated by a $\sim 4$-hour rest time.

CRITICAL STEP: Before performing these experiments, it is important to determine the radiation dosage required with the strain, sex, and age of mice being used. For female C57BL/6 mice at 812 weeks, the typical lethal radiation dose is $9.5 \mathrm{~Gy}$ but this should be confirmed with your irradiator and mouse strain.

Ii) Whole bone marrow cells should be collected from a euthanized 8-12-week old CD45.1/CD45.2 mice. Spray euthanized mice with 70\% ethanol to prevent the spread of hair and dander. Dissect out femurs, tibias, and pelves from euthanized mice and place in a dish containing 5-10 ml PBS.

CAUTION: Mouse euthanasia should be performed in accordance with relevant national and institutional guidelines and regulations.

CRITICAL STEP: Keep all bone marrow cells on ice as much as possible throughout the collection process.

Iii) Remove muscle by cleaning bones with Kimtech wipes, cut the ends of each bones, and place in a tissue culture plate containing 5-10 ml PBS. 
Iv) Flush the bone marrow from the bones using a $5 \mathrm{ml}$ syringe and 25-gauge needle, and generate a single cell suspension by drawing the bone marrow through the needle once or twice.

CAUTION: Be careful with sharp needles. Do not re-sheath. Dispose safely according to institutional guidelines.

CRITICAL STEP: Bone flushing is used here so that only bone marrow cells are collected and transplanted. Although bone crushing (as described above) could be used, it results in collection of not only marrow cells but also bone cells and associated debris, which make it difficult to accurately count whole bone marrow cells.

V) Transfer the single cell suspension through a $50 \mu \mathrm{m}$ filter into a $15 \mathrm{ml}$ tube. Wash the plate and bones with $5 \mathrm{ml}$ PBS and transfer into the tube through the same filter. Invert the $15 \mathrm{ml}$ tube to mix the cell suspension and then remove 10 $\mu \mathrm{l}$ for cell counting. Count the cell number using a hematocytometer. We recommend diluting the cells 1:5-1:10 vol/vol in Turk's solution to achieve accurate cell counting.

Vi) Centrifuge the whole bone marrow cells at $440 \mathrm{~g}$ for 5 minutes at $4{ }^{\circ} \mathrm{C}$, remove the supernatant, flick the tube to disrupt the pellet, and resuspend at $2 \times 10^{7}$ cells/ml in PBS (or $1 \times 10^{6}$ cells per $50 \mu \mathrm{l}$ ). Keep CD45.1/CD45.2 whole bone marrow cells on ice until ready to mix with donor cells. Ensure that the cell suspension is homogeneous before transfer.

CAUTION: As you may lose cells during the centrifugation step, we recommend recounting the cells to confirm that cells are at $2 \times 10^{7}$ cells $/ \mathrm{ml}$ (and adjust as necessary).

Viii) Collect cultured CD45.1 donor cells from your HSC cultures in up to $200 \mu \mathrm{l}$ media or PBS in a sterile $1.5 \mathrm{ml}$ tube by gently wash the plate bottom to dissociate the HSCs. If necessary, larger volumes of HSCs can be centrifuged at $440 \mathrm{~g}$ for 5 minutes at $4^{\circ} \mathrm{C}$ and resuspended in $200 \mu \mathrm{l}$ PBS (keep on ice until transplantation).

CRITICAL STEP: On fibronectin coated plates, HSCs are only lightly attached to the plate bottom. Gentle washing of the plate bottom with the culture media using a pipette is sufficient to lift the HSCs. Aggressive mixing may reduce cell viability.

iX) Add $1 \times 10^{6} \mathrm{CD} 45.1 / \mathrm{CD} 45.2$ whole bone marrow cells (typically $50 \mu \mathrm{l}$ ) to each tube/well. Keep cells on ice until transplantation. Transplant the mixture of donor and competitor cells into the recipient mice by retro-orbital or tail-vein injection using a $1 \mathrm{ml} 27$-gauge needle following the second dose of irradiation.

CAUTION: Ensure that all animal protocols have institutional approval. Ensure that appropriate analgesia is provided to the recipients as necessary. Monitor the mice following radiation and transplantation, particularly where analgesia is used.

X) Perform peripheral blood analysis every 4-weeks, as described in option A steps iii-vii. Secondary transplantation analysis can also be performed by collecting bone marrow from recipient mice, as described in option B steps i-vi, and then 
transplanting $1 \times 10^{6}$ whole bone marrow cells from the primary recipient into lethally-irradiated secondary recipient mice, as described in option B step ix. Peripheral blood analysis should then be performed every 4-weeks until at least 12 weeks post-transplantation, as described in option A, steps iii-vii.

\section{TIMING}

Make sure you allow enough time to train, access, order, and/or breed experimental mice for this protocol (with institutionally-approved protocols), and to train and/or access appropriate FACS facilities. These steps may take several months. The estimated timing for the specific protocol steps below assumes all reagents and animals are ready and available.

Preparing reagents: 1-2 hours hands-on, 6-8 hours total.

Collecting mouse HSCs by FACS, steps 1-18: 4-5 hours hands-on, 6-8 hours total (depending on the number of donors).

Culture of mouse HSCs (bulk or clonal), steps 19A or 19B: 30-60 minutes hands-on, once every 2-3 days for the duration of the culture (up to 1-2 months).

Flow cytometric analysis of HSCs cultures, steps 20-24:2-3 hours hands-on per timepoint (depending on the number of samples).

Transplantation analysis in nonconditioned recipients, step 25A: 1-2 hours hands-on per day for 3 consecutive days for transplantation, then 3-6 hours hands-on (depending on the number of samples) once every 4 weeks for a total of 16 weeks.

Competitive transplantation analysis in irradiated recipients, step 25B:3-4 hours hands-on, 6-8 hours total for transplantation (depending on the number of transplants), then 3-6 hours hands-on (depending on the number of samples) once every 4 weeks for a total of 16 weeks.

\section{TROUBLESHOOTING}

See Table 1 for troubleshooting guidance

\section{ANTICIPATED RESULTS}

Typical results from this HSC culture protocol have been previously described in detail ${ }^{8}$. Briefly, in terms of cell numbers: for cultures initiated from 50 HSCs, you should expect 1$2 \times 10^{4}$ cells by day 7 and $4-5 \times 10^{5}$ cells by day 28 . To generate more cells, the volume/size of the cultures need to be increased by splitting the cultures into multiple 96-well plates or expanding to 24-well plates. Within the cultures, the phenotypic populations should remain fairly stable and you should expect retention of $\sim 30-50 \% \mathrm{KSL}$ cells throughout the culture, of which at least $40 \%$ retain CD150 expression (Figure 4,5). However, this can vary depending on the starting population, the frequency (and accuracy) of media changes, and quality of reagents. Additionally, far more heterogeneity in cell number and phenotype will be seen when analyzing clonally-derived cultures, where Lineage ${ }^{+}$cell-dominated cultures are frequently observed. Following transplantation into irradiated recipients, even just $1 \times 10^{4}$ 
cells from a day-28 bulk HSC culture should engraft at high levels in competitive transplantation assays and display stable multilineage output in primary and secondary recipients. Low donor myeloid (CD11b/Ly-6G) output by 16-weeks usually signifies loss of HSC activity ${ }^{11}$. Similar levels of chimerism within the bone marrow HSC compartment should also be seen.

\section{Supplementary Material}

Refer to Web version on PubMed Central for supplementary material.

\section{ACKNOWLEDGEMENTS}

We thank M. Odai for filming. This research was funded by JSPS KAKENHI Grant-in-Aid for Scientific Research (JP18H05095; JP17H05086), Japan Agency for Medical Research and Development (JP18bm0404025), CIRM (LA1_C12-06917; DISC1-10555), the NIH (R01DK116944; R01HL147124; R21AG061487) and the Ludwig Foundation. ACW was funded by Bloodwise (15050), the Leukemia and Lymphoma Society (3385-19), and the JSPS.

\section{REFERENCES}

1. Eaves CJ. Hematopoietic stem cells: concepts, definitions, and the new reality. Blood. 2015;125(17):2605-2613. [PubMed: 25762175]

2. Seita J, Weissman IL. Hematopoietic stem cell: self-renewal versus differentiation. Wiley Interdiscip Rev Syst Biol Med. 2010;2(6):640-653. [PubMed: 20890962]

3. Orkin SH, Zon LI. Hematopoiesis: An evolving paradigm for stem cell biology. Cell. 2008;132(4):631-644. [PubMed: 18295580]

4. Yamamoto R, Wilkinson AC, Nakauchi H. Changing concepts in hematopoietic stem cells. Science. 2018;362(6417):895-896. [PubMed: 30467158]

5. Osawa M, Hanada K, Hamada H, Nakauchi H. Long-term lymphohematopoietic reconstitution by a single CD34-low/negative hematopoietic stem cell. Science. 1996;273(5272):242-245. [PubMed: 8662508]

6. Copelan EA. Hematopoietic stem-cell transplantation. N Engl J Med. 2006;354(17):1813-1826. [PubMed: 16641398]

7. Kumar S, Geiger H. HSC Niche Biology and HSC Expansion Ex Vivo. Trends Mol Med. 2017;23(9):799-819. [PubMed: 28801069]

8. Wilkinson AC, Ishida R, Kikuchi M, et al. Long-term ex vivo haematopoietic-stem-cell expansion allows nonconditioned transplantation. Nature. 2019;571(7763):117-121. [PubMed: 31142833]

9. Ieyasu A, Ishida R, Kimura T, et al. An All-Recombinant Protein-Based Culture System Specifically Identifies Hematopoietic Stem Cell Maintenance Factors. Stem Cell Reports. 2017;8(3):500-508. [PubMed: 28238792]

10. Yamamoto R, Morita Y, Ooehara J, et al. Clonal analysis unveils self-renewing lineage-restricted progenitors generated directly from hematopoietic stem cells. Cell. 2013;154(5):1112-1126. [PubMed: 23993099]

11. Yamamoto R, Wilkinson AC, Ooehara J, et al. Large-Scale Clonal Analysis Resolves Aging of the Mouse Hematopoietic Stem Cell Compartment. Cell Stem Cell. 2018;22(4):600-607.e604. [PubMed: 29625072]

12. Cabezas-Wallscheid N, Klimmeck D, Hansson J, et al. Identification of regulatory networks in HSCs and their immediate progeny via integrated proteome, transcriptome, and DNA methylome analysis. Cell Stem Cell. 2014;15(4):507-522. [PubMed: 25158935]

13. Ramsfjell V, Borge OJ, Veiby OP, et al. Thrombopoietin, but not erythropoietin, directly stimulates multilineage growth of primitive murine bone marrow progenitor cells in synergy with early acting cytokines: distinct interactions with the ligands for c-kit and FLT3. Blood. 1996;88(12):44814492. [PubMed: 8977240] 
14. Seita J, Ema H, Ooehara J, et al. Lnk negatively regulates self-renewal of hematopoietic stem cells by modifying thrombopoietin-mediated signal transduction. Proc Natl Acad Sci U S A. 2007;104(7):2349-2354. [PubMed: 17284614]

15. Kiel MJ, Yilmaz OH, Iwashita T, Terhorst C, Morrison SJ. SLAM family receptors distinguish hematopoietic stem and progenitor cells and reveal endothelial niches for stem cells. Cell. 2005;121(7):1109-1121. [PubMed: 15989959]

16. Morita Y, Ema H, Nakauchi H. Heterogeneity and hierarchy within the most primitive hematopoietic stem cell compartment. J Exp Med. 2010;207(6):1173-1182. [PubMed: 20421392]

17. Ema H, Morita Y, Yamazaki S, et al. Adult mouse hematopoietic stem cells: purification and single-cell assays. Nat Protoc. 2006;1(6):2979-2987. [PubMed: 17406558]

18. Challen GA, Boles N, Lin KK, Goodell MA. Mouse hematopoietic stem cell identification and analysis. Cytometry A. 2009;75(1):14-24. [PubMed: 19023891]

19. Lo Celso C, Scadden D. Isolation and transplantation of hematopoietic stem cells (HSCs). J Vis Exp. 2007(2):157 doi: 10.3791/157. [PubMed: 18830434]

20. Frascoli M, Proietti M, Grassi F. Phenotypic analysis and isolation of murine hematopoietic stem cells and lineage-committed progenitors. J Vis Exp. 2012(65). doi: 10.3791/3736.

21. Bhattacharya D, Rossi DJ, Bryder D, Weissman IL. Purified hematopoietic stem cell engraftment of rare niches corrects severe lymphoid deficiencies without host conditioning. J Exp Med. 2006;203(1):73-85. [PubMed: 16380511]

22. Shimoto M, Sugiyama T, Nagasawa T. Numerous niches for hematopoietic stem cells remain empty during homeostasis. Blood. 2017;129(15):2124-2131. [PubMed: 28130213]

23. Purton LE, Scadden DT. Limiting factors in murine hematopoietic stem cell assays. Cell Stem Cell. 2007;1(3):263-270. [PubMed: 18371361]

24. Wilson NK, Kent DG, Buettner F, et al. Combined Single-Cell Functional and Gene Expression Analysis Resolves Heterogeneity within Stem Cell Populations. Cell Stem Cell. 2015;16(6):712724. [PubMed: 26004780]

25. Luchsinger LL, Strikoudis A, Danzl NM, et al. Harnessing Hematopoietic Stem Cell Low Intracellular Calcium Improves Their Maintenance In Vitro. Cell Stem Cell. 2019 25(2):225240.e7. doi: 10.1016/j.stem.2019.05.002. [PubMed: 31178255]

26. Slukvin II. Hematopoietic specification from human pluripotent stem cells: current advances and challenges toward de novo generation of hematopoietic stem cells. Blood. 2013;122(25):40354046. [PubMed: 24124087]

27. Slukvin II, Uenishi GI. Arterial identity of hemogenic endothelium: a key to unlock definitive hematopoietic commitment in human pluripotent stem cell cultures. Exp Hematol. 2019;71:3-12. [PubMed: 30500414]

28. Wilkinson AC, Ryan DJ, Kucinski I, et al. Expanded Potential Stem Cell Media as a tool to study human developmental hematopoiesis in vitro. Exp Hematol. 2019 DOI: 10.1016/ j.exphem.2019.07.003

29. Fares I, Chagraoui J, Gareau Y, et al. Cord blood expansion. Pyrimidoindole derivatives are agonists of human hematopoietic stem cell self-renewal. Science. 2014;345(6203):1509-1512. [PubMed: 25237102]

30. Boitano AE, Wang J, Romeo R, et al. Aryl hydrocarbon receptor antagonists promote the expansion of human hematopoietic stem cells. Science. 2010;329(5997):1345-1348. [PubMed: 20688981]

31. Csaszar E, Kirouac DC, Yu M, et al. Rapid expansion of human hematopoietic stem cells by automated control of inhibitory feedback signaling. Cell Stem Cell. 2012;10(2):218-229. [PubMed: 22305571]

32. Dever DP, Bak RO, Reinisch A, et al. CRISPR/Cas9 $\beta$-globin gene targeting in human haematopoietic stem cells. Nature. 2016;539(7629):384-389. [PubMed: 27820943]

33. Bak RO, Dever DP, Porteus MH. CRISPR/Cas9 genome editing in human hematopoietic stem cells. Nat Protoc. 2018;13(2):358-376. [PubMed: 29370156] 


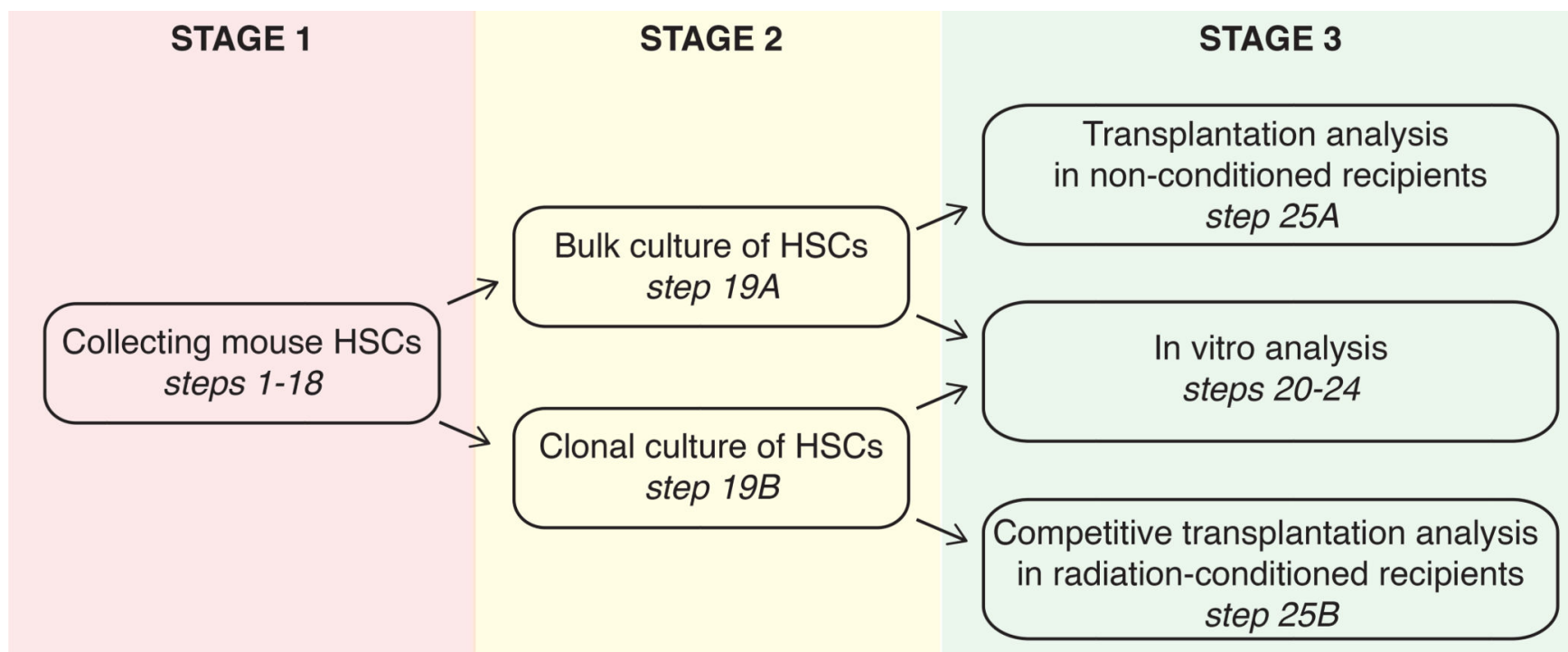

Figure 1: Schematic overview of the HSC expansion culture protocol

HSCs are first isolated from mouse bone marrow (steps 1-18) to initiated to initiate either bulk HSC cultures (step 19A) or clonal HSC cultures (step 19B). Following ex vivo HSC expansion, the derived cultures can then be analyzed in vitro (steps 20-24), or in vivo by transplantation into nonconditioned recipient mice (step 25A) or radiation-conditioned recipient mice (step $25 B$ ). 

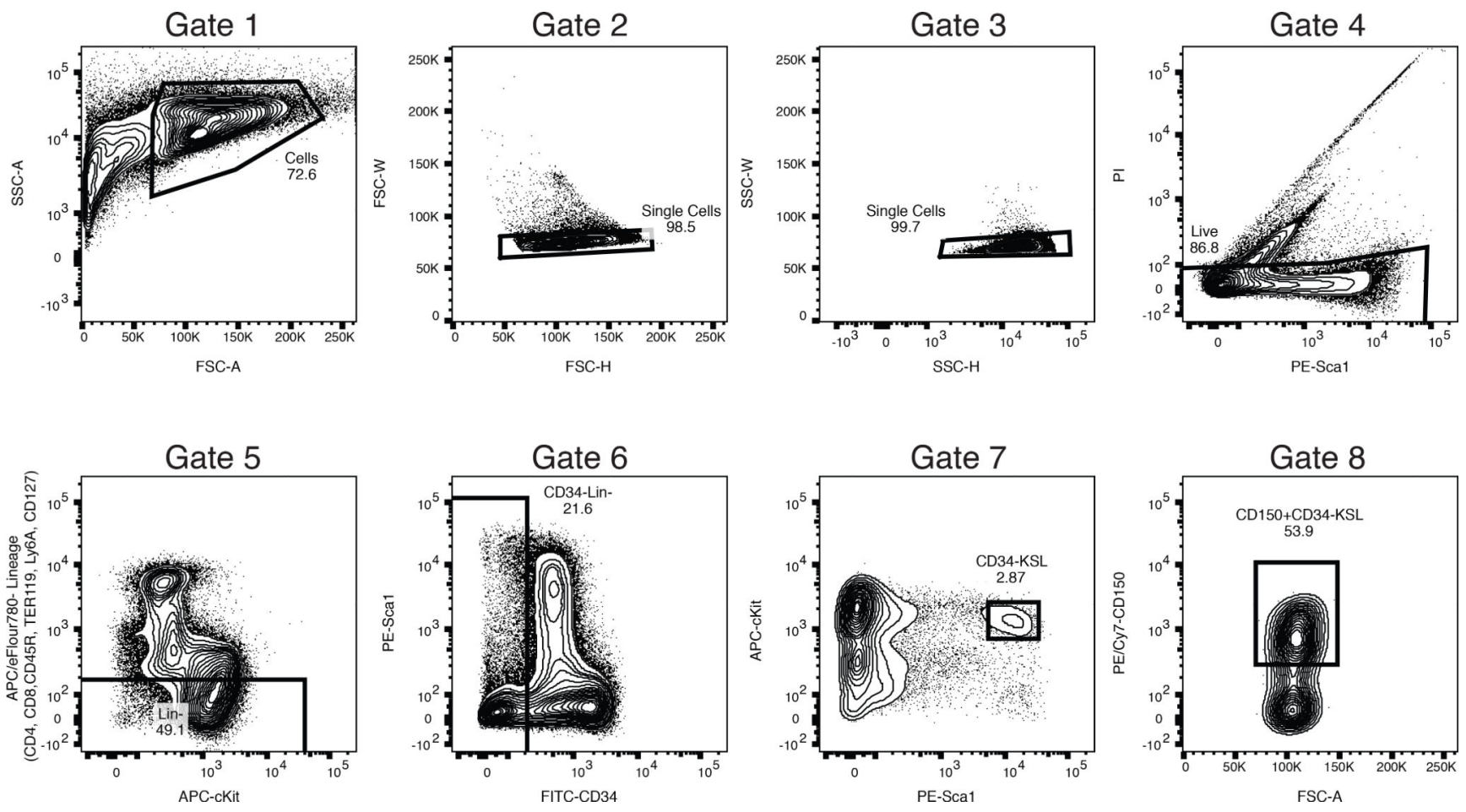

Figure 2: Representative gating scheme for FACS purification of bone marrow HSCs Live CD $150^{+} \mathrm{CD} 34^{-} \mathrm{Kit}^{+} \mathrm{Sca} 1^{+}{ }^{-}$ineage ${ }^{-}\left(\mathrm{CD} 150^{+} \mathrm{CD} 34^{-} \mathrm{KSL}\right)$ HSCs should be isolated by FACS from c-Kit-enriched mouse bone marrow using the following gating scheme, and directly sorted into wells containing fresh HSC media. 


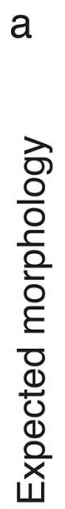

Day 8

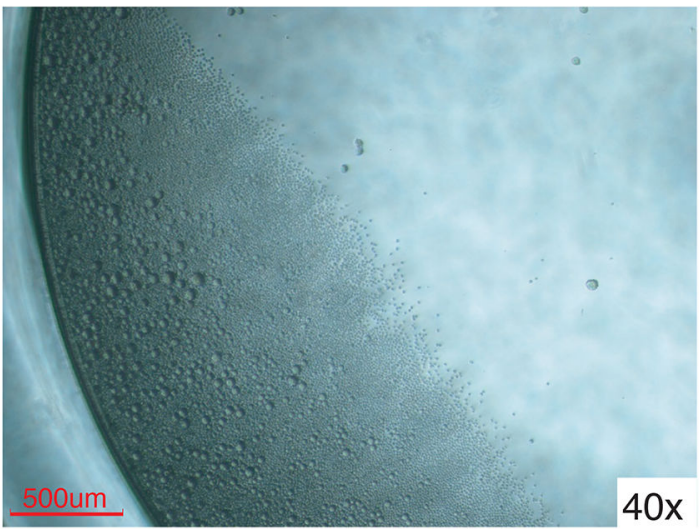

Day 24

b

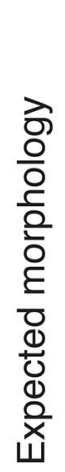

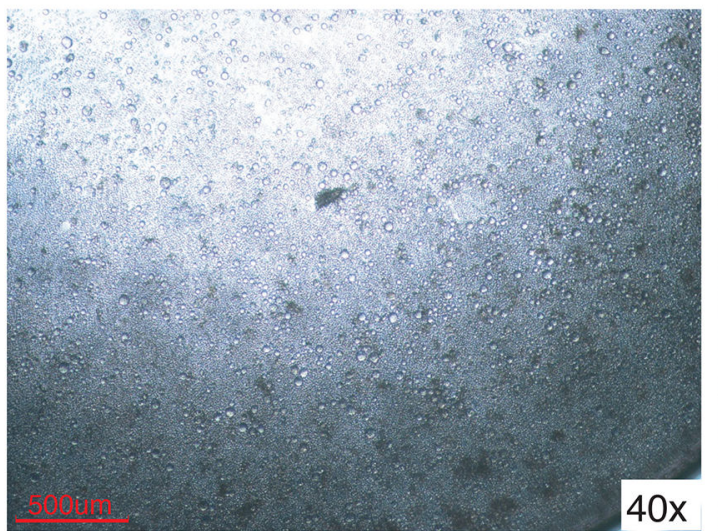

Day 10

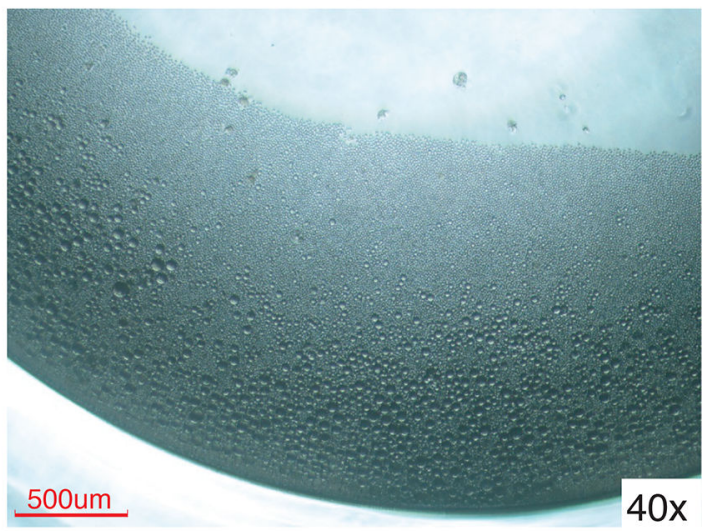

Day 37
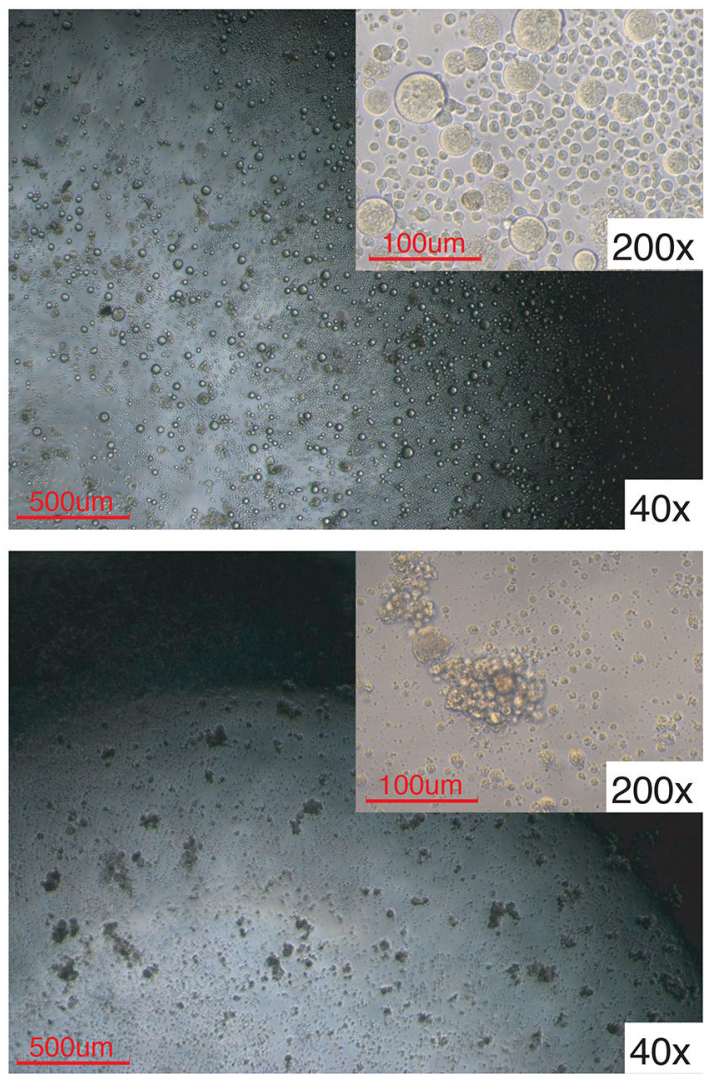

Figure 3: Representative images of mouse HSC cultures

(A) Representative images of usual cell density of bulk HSC cultures after 8 and 10 days. Cultures tend from one side of the well and expand out. The majority of cells should be small and round, although some larger (megakaryocyte-like) cells are expected in the cultures. Where possible, perform media changes from the opposite side of the well to minimize disturbing the cells. Images at 40x magnification.

(B) Representative images of expected cell morphology at day 24 and 37 (above) and images displaying evidence of cell differentiation (below). Evidence of cell clumping and cell death 
are indicators of bad HSC cultures. Images at 40x magnification, with insert images at 200x magnification. 

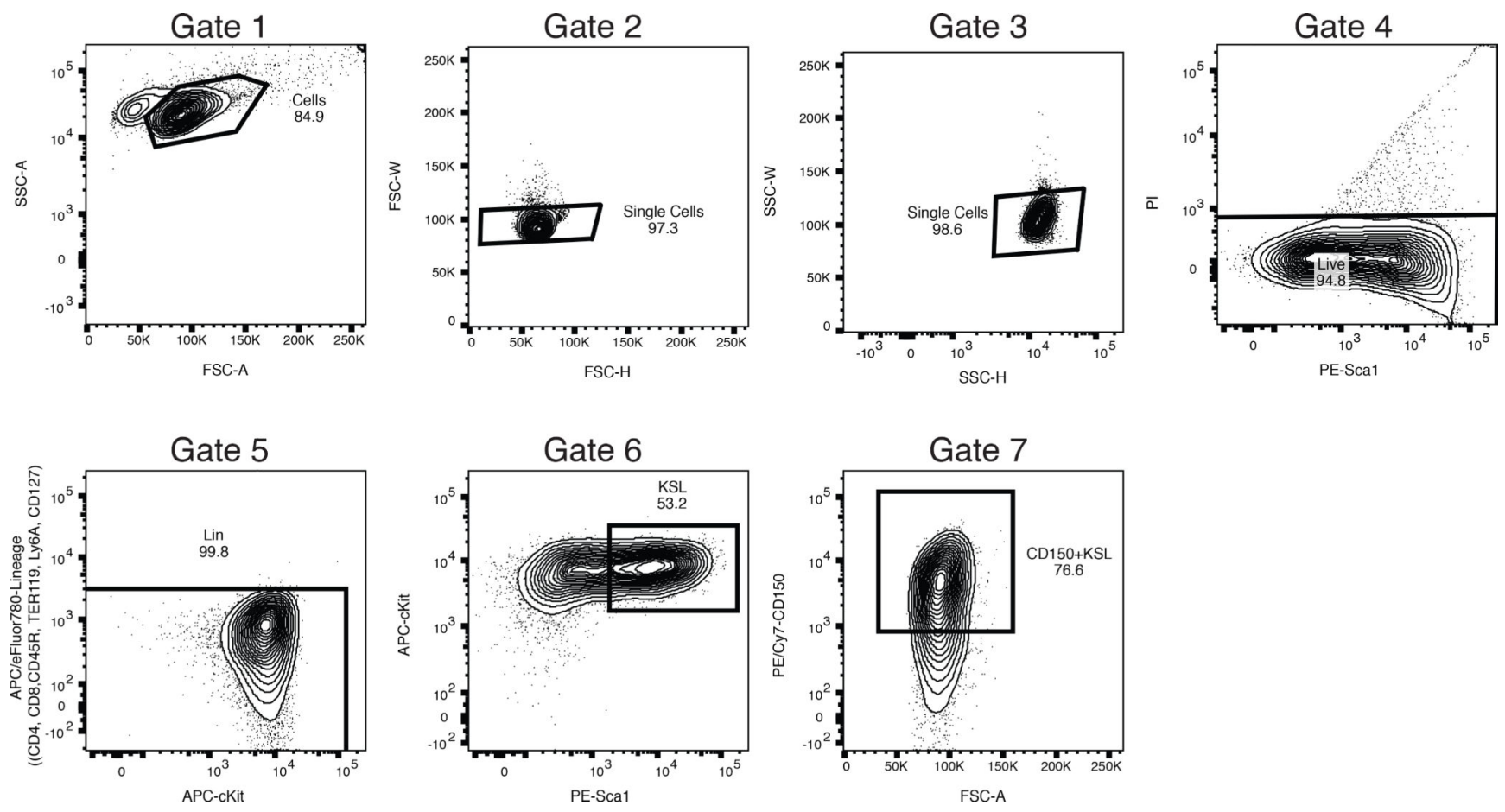

Figure 4: Representative gating scheme for flow cytometric analysis of HSC cultures HSC cultures should be analyzed by flow cytometry using the following gating scheme, to determine expression of Kit, Sca1, Lineage, CD150, and PI staining. This example staining profile phenotype is representative of the cultures that should be observed from bulk HSC culture. 
Example good cultures
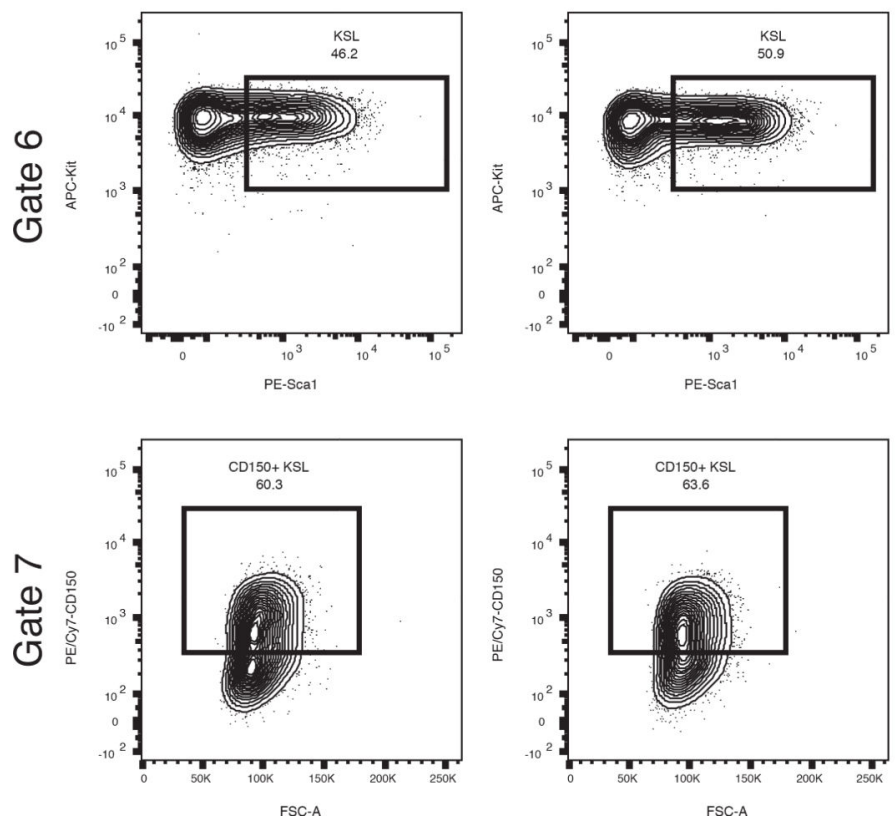
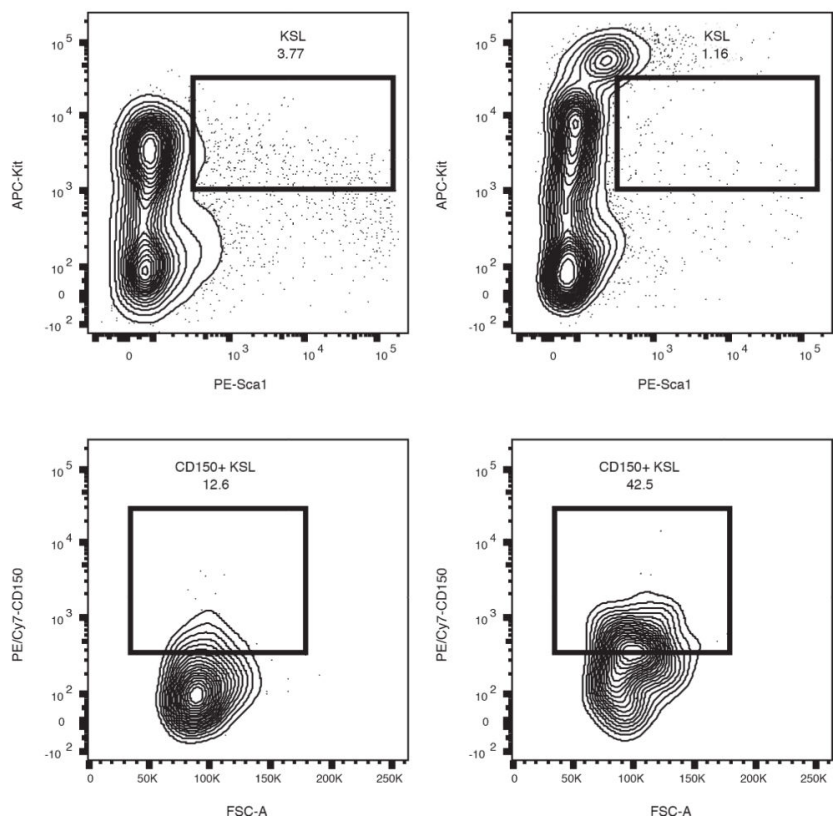

Figure 5: Example flow cytometric analysis of HSC cultures

Example flow cytometry plots of good and bad HSC cultures analyzed at day 28 using the gating scheme described in Figure 4. 

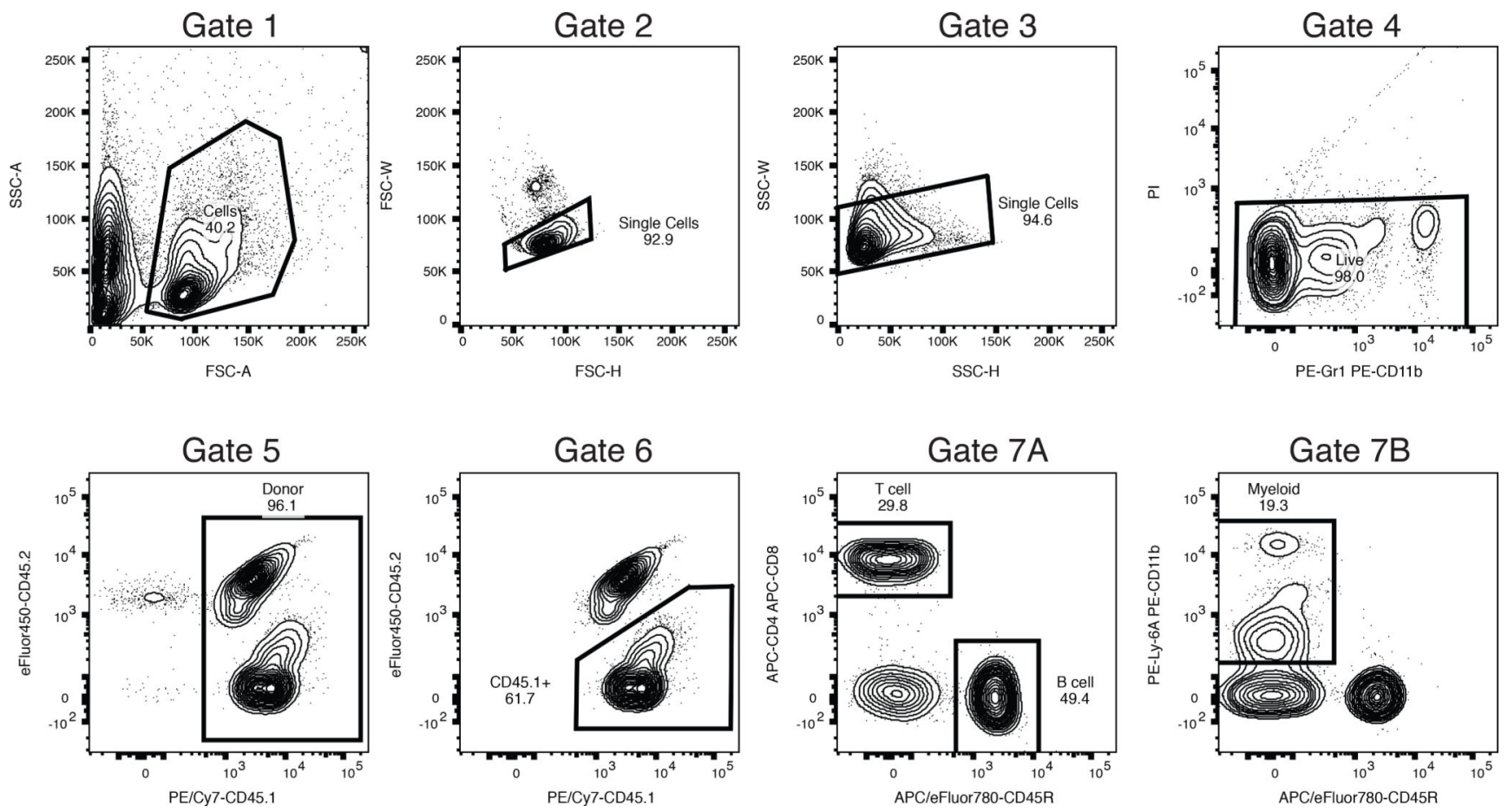

Figure 6: Representative gating scheme for flow cytometric peripheral blood analysis The peripheral blood of transplantation recipient mice should be analyzed by flow cytometry using the following gating scheme, to determine the relative donor chimerism of engrafting HSCs. 

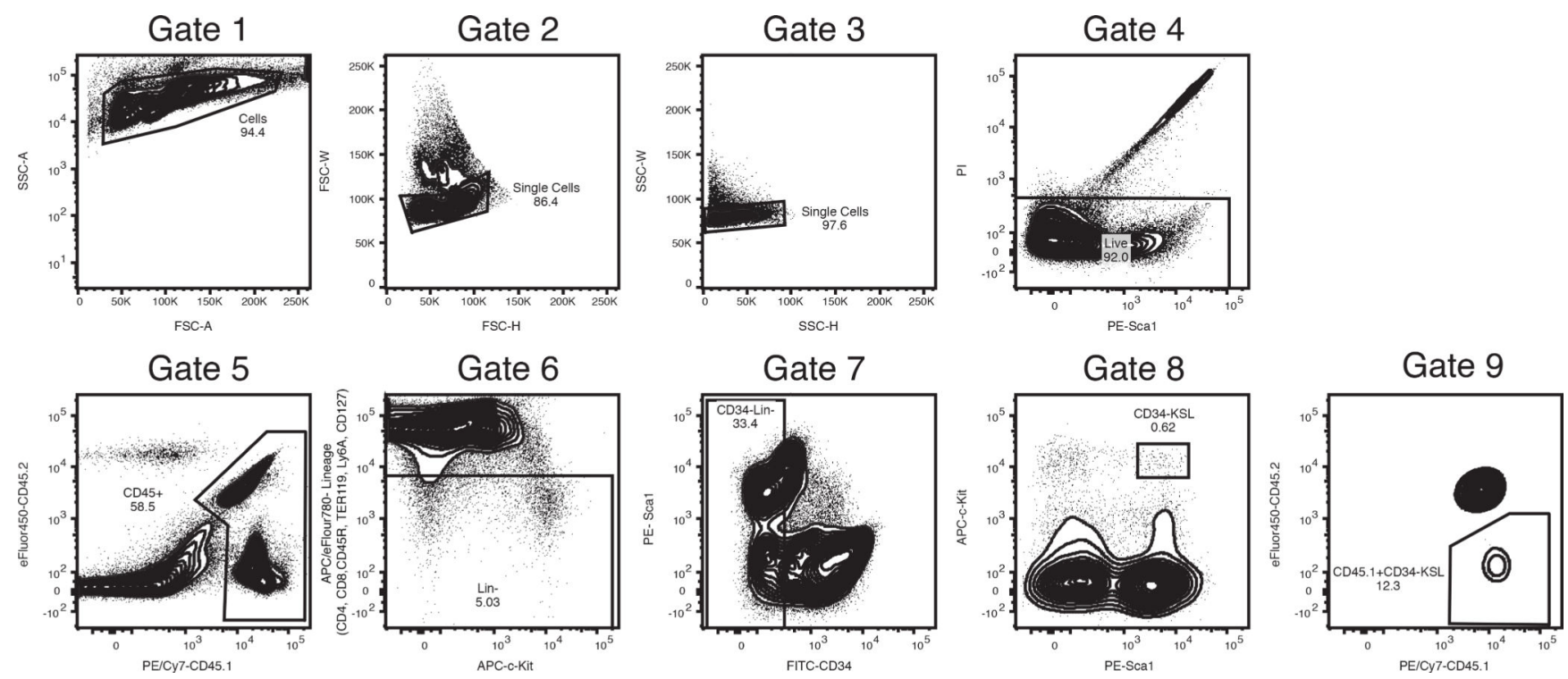

Figure 7: Representative gating scheme for flow cytometric bone marrow analysis The bone marrow of transplantation recipient mice should be analyzed by flow cytometry using the following gating scheme, to determine the relative donor chimerism of engrafting HSCs within the CD34-KSL HSC compartment. 
Table 1:

Troubleshooting

\begin{tabular}{|c|c|c|c|}
\hline Step & Problem & Possible Reason & Solution \\
\hline \multirow[t]{2}{*}{19} & Media evaporation & Low humidity incubator & Refill incubator with water. \\
\hline & & Use of outer plate wells. & $\begin{array}{l}\text { Fill outer plate wells (and any unused cells in the plate) with } \\
\text { PBS. Only use inner wells for cell culture. }\end{array}$ \\
\hline \multirow[t]{3}{*}{19} & $\begin{array}{l}\text { No cells after } \\
\text { culture }\end{array}$ & $\begin{array}{l}\text { Low accuracy or purity during FACS } \\
\text { isolation }\end{array}$ & $\begin{array}{l}\text { Confirm accuracy by test sorting. Confirm purity by analysis } \\
\text { of freshly sorted cells. }\end{array}$ \\
\hline & & Poorly-calibrated tissue culture incubator & Get tissue culture incubator professionally serviced. \\
\hline & & Removing cells during media changes & $\begin{array}{l}\text { Perform media changes gently and check whether cells are } \\
\text { contained in the removed media (note: it is normal for some } \\
\text { cells to be removed with the media). }\end{array}$ \\
\hline 19 & $\begin{array}{l}\text { Large polypoid cells } \\
\text { are observed in the } \\
\text { culture }\end{array}$ & $\begin{array}{l}\text { These are likely due to the high TPO } \\
\text { conditions supporting megakaryopoiesis }\end{array}$ & $\begin{array}{l}\text { These cells do not appear to dramatically inhibit the culture, } \\
\text { and a small percentage of these cells is normal. If large } \\
\text { numbers are observed, consider testing new cytokine batches. }\end{array}$ \\
\hline 19 & $\begin{array}{l}\text { Dead cells observed } \\
\text { in the HSC cultures }\end{array}$ & $\begin{array}{l}\text { Non-HSCs are poorly supported in healthy } \\
\text { HSC cultures and are the likely cause of this } \\
\text { cell debris. High viability should be seen at } \\
\text { early time points ( }>95 \% \text { at day } 7 \text { ), but dead } \\
\text { cells may accumulate by day } 28 \text { (to } \sim 20 \% \text { ). }\end{array}$ & $\begin{array}{l}\text { Perform more regular media changes to help remove the } \\
\text { debris. Cell death of non-HSCs is likely important to prevent } \\
\text { progenitor overgrowth but lots of debris may inhibit the } \\
\text { cultures. Consider passaging the culture (e.g. split one well } \\
\text { into three wells) }\end{array}$ \\
\hline \multirow[t]{2}{*}{24} & $\begin{array}{l}\text { Low frequency of } \\
\text { KSL after culture or } \\
\text { low chimerism in } \\
\text { recipients }\end{array}$ & $\begin{array}{l}\text { Loss of cytokine activity (cultures are } \\
\text { particularly dependent on high TPO } \\
\text { concentrations) }\end{array}$ & $\begin{array}{l}\text { Purchase new batch of cytokines, stock at }-80^{\circ} \mathrm{C} \text { and } \\
\text { immediately thaw before use. }\end{array}$ \\
\hline & & Media components being used up & $\begin{array}{l}\text { Perform media changes every } 48 \text { hours; passage HSC cultures } \\
\text { to reduce cell density. }\end{array}$ \\
\hline 25 & $\begin{array}{l}\text { Low chimism in } \\
\text { recipients }\end{array}$ & $\begin{array}{l}\text { Low frequency of HSCs after culture due to } \\
\text { poorly optimized cultures }\end{array}$ & $\begin{array}{l}\text { Use frequency of KSL after culture as an immediate readout } \\
\text { for HSC culture stability and test troubleshooting steps above. }\end{array}$ \\
\hline
\end{tabular}

